\title{
Role of Sphingolipids and Metabolizing Enzymes in Hematological Malignancies
}

\author{
Kazuyuki Kitatani, ${ }^{1,2}$, Makoto Taniguchi ${ }^{3}$, and Toshiro Okazak ${ }^{\beta, 4, *}$
}

\begin{abstract}
Sphingolipids such as ceramide, sphingosine-1-phosphate and sphingomyelin have been emerging as bioactive lipids since ceramide was reported to play a role in human leukemia HL-60 cell differentiation and death. Recently, it is well-known that ceramide acts as an inducer of cell death, that sphingomyelin works as a regulator for microdomain function of the cell membrane, and that sphingosine-1phosphate plays a role in cell survival/proliferation. The lipids are metabolized by the specific enzymes, and each metabolite could be again returned to the original form by the reverse action of the different enzyme or after a long journey of many metabolizing/synthesizing pathways. In addition, the metabolites may serve as reciprocal biomodulators like the rheostat between ceramide and sphingosine-1-phosphate. Therefore, the change of lipid amount in the cells, the subcellular localization and the downstream signal in a specific subcellular organelle should be clarified to understand the pathobiological significance of sphingolipids when extracellular stimulation induces a diverse of cell functions such as cell death, proliferation and migration. In this review, we focus on how sphingolipids and their metabolizing enzymes cooperatively exert their function in proliferation, migration, autophagy and death of hematopoetic cells, and discuss the way developing a novel therapeutic device through the regulation of sphingolipids for effectively inhibiting cell proliferation and inducing cell death in hematological malignancies such as leukemia, malignant lymphoma and multiple myeloma.
\end{abstract}

\section{INTRODUCTION}

Sphingolipids have been emerged as a bioactive lipid to regulate a myriad of cell functions including cell death, prolifera-

\footnotetext{
${ }^{1}$ Tohoku Medical Megabank Organization, ${ }^{2}$ Department of Obstetrics and Gynecology, Tohoku University Graduate School of Medicine, Tohoku University, Sendai, Japan, ${ }^{3}$ Medical Research Institute, Kanazawa Medical University, ${ }^{4}$ Department of Medicine, Division of Hematology/Immunology, Kanazawa Medical University, Uchinada, Ishikawa 920-0293, Japan

${ }^{\star}$ Correspondence: toshiroo@ kanazawa-med.ac.jp
}

Received 4 May, 2015; accepted 7 May, 2015; published online 22 May, 2015

Keywords: ceramide, leukemia , lymphoma, sphingolipid, sphingomyelin tion/survival, autophagy, migration, secretion and immunity (Adada et al., 2014; Maceyka and Spiegel, 2014; Truman et al., 2014). Among sphingolipids, ceramide was firstly reported to induce cell differentiation and death in human leukemia HL-60 cells (Obeid et al., 1993; Okazaki et al., 1989). To clarify the mechanism to induce cell death, the subcellular compartmentalization of active ceramide, the putative diverse function among ceramide molecular species and its regulation by metabolic enzymes have been investigated in several kinds of cancers (Gault et al., 2010; Park et al., 2014). Recently, sphingosine-1-phosphate (S1P) and sphingomyelin (SM) are also recognized as biological regulators in many cell functions. Ceramide induces apoptosis, autophagy and senescence (Truman et al., 2014) while S1P acts as an extracellular mediator for cell survival and migration, an inhibitor of autophagy and a regulator of innate and adaptive immunity (Degagne and Saba, 2014). SM has been thought as a reservoir of ceramide because ceramide is generated through hydrolysis of SM by sphingomyelinases (SMases). Additionally, it becomes clear that SM per se modulates the trans-membrane signals through microdomains and the intracellular vesicular trafficking (Taniguchi and Okazaki, 2014). Therefore, at present the metabolic regulation of bioactive sphingolipids takes an attention as a key for understanding cell death, proliferation and migration in the pathological malignant condition. It is critical to clarify the role for sphingolipids in the regulation of the signal balance between cell proliferation/survival and death, in order to develop a novel therapy for hematological malignant disorders such as leukemia, malignant lymphoma and multiple myeloma.

In this review, we focus on the recent progress of the research for investigating the biological implications of sphingolipids in the regulation of hematological malignant cells and show a bird's-eye view image of sphingolipid action for developing a novel therapeutic way. We also discuss the intracellular localization of sphingolipids and their metabolizing enzymes and the reciprocal role of sphingolipids in cell proliferation/survival and death in hematopoietic cells.

\section{METABOLISM OF SPHINGOLIPIDS (CERAMIDE, S1P, AND SM)}

Sphingolipid anabolism and catabolism are important for cellular homeostasis and a number of enzymes are involved in the metabolism. Intensive studies revealed individual responsible genes, biochemical characteristics, subcellular localization and regulation (Fig.1 and Tables 1-4).

Individual enzyme is compartmentalized in specific subcellu- 


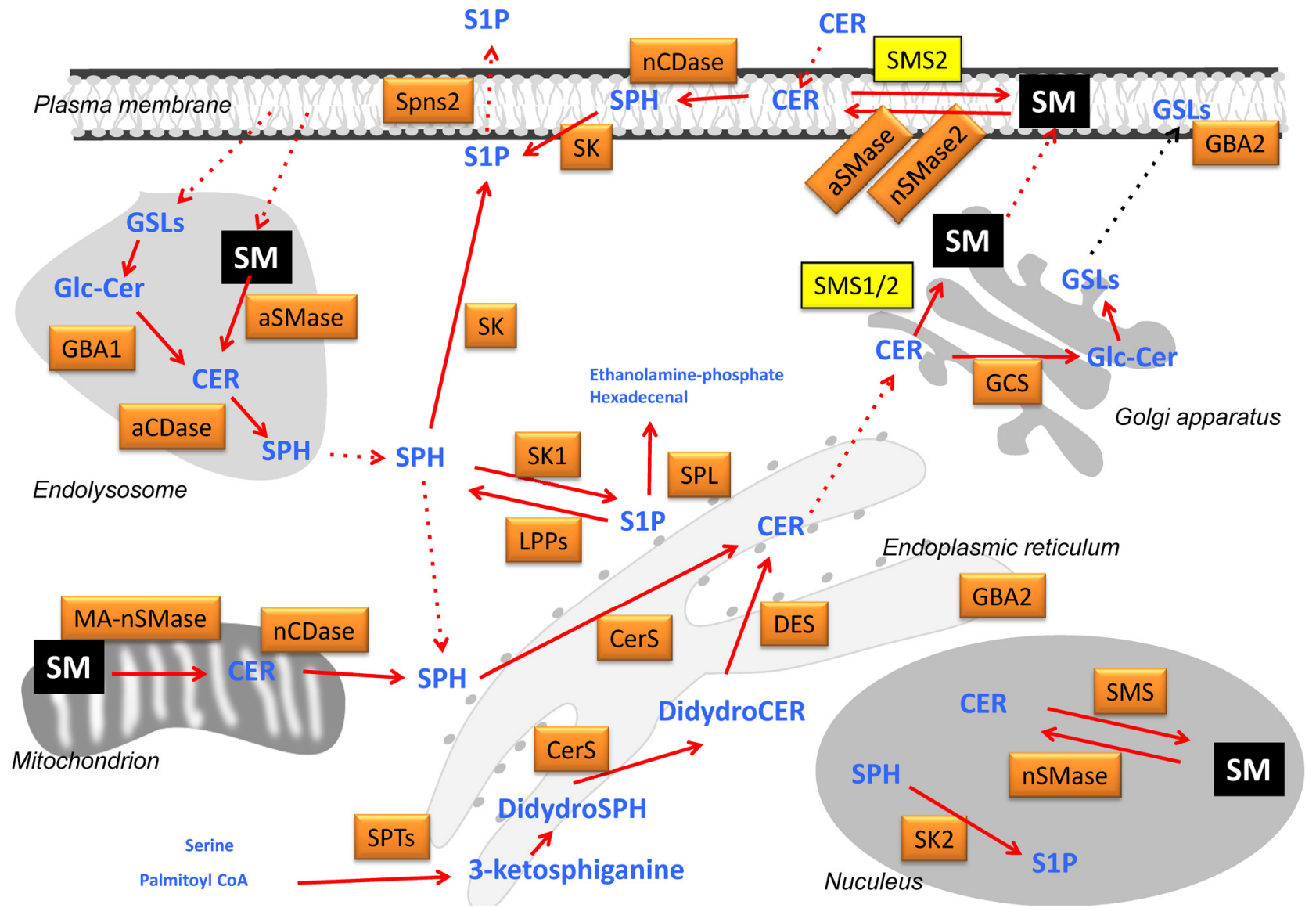

Fig. 1. Sphingolipid metabolism and subcellular compartmentalization. A diverse sphingolipids are synthesized and degraded through complex metabolizing pathways in each intracellular compartment. For example, SM (colored by yellow) is synthesized in Golgi apparatus by SMS1 and SMS2, and in plasma membrane by SMS2, and resides in endosomes, lysosomes, mitochondria and nucleus. Each SM is suggested to play a role as a regulator of micro-organelles and a source of other bioactive sphingolipids.

lar organelle. In endoplasmic reticulum, de novo synthesis of sphingolipids begins with the condensation of palmitoyl-CoA and serine by the catalytic action of serine palmitoyl acyltransferase (SPT) (Hanada, 2003; Hanada et al., 2000), generating 3ketosphinganine. This intermediate is converted to dihydrosphingosine that serves as a substrate for ceramide synthase (CerS) to form dihydroceramide. Ceramide desaturase (DES1) (Rodriguez-Cuenca et al., 2015) catalyzes the synthesis of ceramide from dihydroceramide, which is the last step for the de novo synthesis of ceramide. Those steps occur in endoplasmic reticulum, and ceramide serves as a building block for most of sphingolipid species. Transport of ceramide by ceramide transfer protein (CERT) (Hanada et al., 2003; Yamaji and Hanada, 2015) and/or other transporting protein (s) to the Golgi are required for the synthesis of ceramide-1-phosphate, $\mathrm{SM}$, galactosylceramide, and glucosylceramide. The last glycolipids are further metabolized to complex sphingolipids.

Most of sphingolipid catabolizing enzymes are localized in endolysosomes, resulting in the formation of lysosomal ceramide (Futerman and Hannun, 2004; Futerman and Riezman, 2005). For instance, lysosomal acid- $\beta$-glucosidase (GBA1) (Dinur et al., 1986; Grabowski, 1993) cleaves glucosylceramide to form ceramide. The lysosomal ceramide is further catabolized to sphingosine by ceramidase (CDase) (Park and Schuchman, 2006). This sphingolipid backbone sphingosine is exploited to generate ceramide through the catalytic action of ceramide synthase at endoplasmic reticulum. This is termed the "salvage pathway" of sphingolipid synthesis (Kitatani et al., 2008; Tettamanti et al., 2003). Exogenous short chain ceramide such as $\mathrm{C}_{6}$-ceramide is recycled into long chain ceramide via that pathway (Kitatani et al., 2008). Alternatively, sphingosine is phosphorylated by sphingosine kinase (SK) (Pitson, 2011), forming S1P that is also degraded or dephosphorylated by S1P lyase (SPL) (Saba and de la GarzaRodea, 2013) or S1P phosphatase (SPP) (Pyne et al., 2009), respectively.

Importantly, ceramide transported to Golgi by CERT is converted to SM by the catalytic action of SM synthase (SMS), and then $\mathrm{SM}$ is distributed to plasma membranes and functions as a component of lipid microdomains. On the other hand, SMase hydrolyses SM to form ceramide in various subcellular organelles. This metabolic cycle between ceramide and SM is known as a "SM-ceramide cycle." Ceramide serves a central lipid in sphingolipid metabolism and is produced via three pathways including de novo synthesis, salvage pathway, and SM-ceramide cycle. 
Role of Sphingolipids and Metabolizing Enzymes in Hematological Malignancies

Kazuyuki Kitatani et al.

Table 1. SMS family

\begin{tabular}{|c|c|c|c|c|}
\hline Name & Developer & SMS1 & SMS2 & SMSr \\
\hline \multirow[t]{2}{*}{$\begin{array}{l}\text { Gene symbol } \\
\text { (Locus) }\end{array}$} & Human & $\begin{array}{c}\text { SGMS1 } \\
\text { (Chr.10 q11.2) }\end{array}$ & $\begin{array}{l}\text { SGMS2 } \\
\text { (Chr.4 q25) }\end{array}$ & $\begin{array}{c}\text { SAMD8 } \\
\text { (Chr.10 q22.2) }\end{array}$ \\
\hline & Mouse & $\begin{array}{c}\text { Sgms1 } \\
\text { (Chr.19 C1) }\end{array}$ & $\begin{array}{c}\text { Sgms2 } \\
\text { (Chr.3 G3) }\end{array}$ & $\begin{array}{l}\text { Samd8 } \\
\text { (Chr.14 B) }\end{array}$ \\
\hline \multirow{2}{*}{$\begin{array}{l}\text { Amino } \\
\text { Acids }\end{array}$} & Human & 413 & 365 & 414 \\
\hline & Mouse & 419 & 365 & 432 \\
\hline Localization & & Golgi & Golgi, Plasma membrane (PM) & ER \\
\hline $\begin{array}{l}\text { Expression } \\
\text { (high) }\end{array}$ & & $\begin{array}{l}\text { Ubiquitous } \\
\text { (islet, testis) }\end{array}$ & $\begin{array}{c}\text { Ubiquitous } \\
\text { (liver, kidney, intestine) }\end{array}$ & $\begin{array}{l}\text { Ubiquitous } \\
\text { (brain) }\end{array}$ \\
\hline \multirow[t]{2}{*}{ Enzymatic effect } & $\begin{array}{c}\text { Substrate } \\
\downarrow \\
\text { Product }\end{array}$ & $\begin{array}{c}\mathrm{Cer}+\mathrm{PC} \\
\downarrow \\
\mathrm{SM}+\mathrm{DAG}\end{array}$ & $\begin{array}{c}\text { Cer }+\mathrm{PC} \\
\downarrow \\
\mathrm{SM}+\mathrm{DAG}\end{array}$ & $\begin{array}{c}\text { Cer }+\mathrm{PE} \\
\downarrow \\
\mathrm{CPE}\end{array}$ \\
\hline & & $\begin{array}{c}\text { Cer }+\mathrm{PE} \\
\downarrow \\
\mathrm{CPE}\end{array}$ & $\begin{array}{c}\text { Cer }+\mathrm{PE} \\
\downarrow \\
\mathrm{CPE}\end{array}$ & \\
\hline
\end{tabular}

Cer, Ceramide; CPE, Ceramide phosphoethanolamine; DAG, Diacylglycerol; PC, Phosphatidylcholine; PE, Phosphatidylethanolamine

Table 2. SMase family

\begin{tabular}{|c|c|c|c|c|c|c|c|c|}
\hline \multirow[b]{2}{*}{ Protein } & \multicolumn{3}{|c|}{ Acid } & \multicolumn{4}{|c|}{ Neutral } & \multirow{2}{*}{$\begin{array}{c}\text { Alkaline } \\
\text { alk-SMase }\end{array}$} \\
\hline & & $\begin{array}{l}\text { L-aSMase } \\
\text { (lysosome) }\end{array}$ & $\begin{array}{l}\text { S-aSMase } \\
\text { (secreted) }\end{array}$ & nSMase1 & nSMase2 & nSMase3 & MA-nSMase & \\
\hline \multirow[t]{2}{*}{$\begin{array}{l}\text { Gene symbol } \\
\text { (Locus) }\end{array}$} & Human & \multicolumn{2}{|c|}{$\begin{array}{c}\text { SMPD1 } \\
\text { (Chr.11 p15.4-15.1) }\end{array}$} & $\begin{array}{l}\text { SMPD2 } \\
\text { (Chr.6 q21) }\end{array}$ & $\begin{array}{c}\text { SMPD3 } \\
\text { (Chr.16 q22.1) }\end{array}$ & $\begin{array}{c}\text { SMPD4 } \\
\text { (Chr.2 q21.1) }\end{array}$ & - & $\begin{array}{c}\text { ENPP7 } \\
\text { (Chr.17 q25.3) }\end{array}$ \\
\hline & Mouse & \multicolumn{2}{|c|}{$\begin{array}{l}\text { Smpd1 } \\
\text { (Chr.7 E3) }\end{array}$} & $\begin{array}{c}\text { Smpd2 } \\
\text { (Chr.10 B2) }\end{array}$ & $\begin{array}{c}\text { Smpd3 } \\
\text { (Chr.8 D2) }\end{array}$ & $\begin{array}{c}\text { Smpd4 } \\
\text { (Chr.16 B1) }\end{array}$ & $\begin{array}{c}\text { Smpd5 } \\
\text { (Chr.15 D3) }\end{array}$ & $\begin{array}{c}\text { ENPP7 } \\
\text { (Chr.11 E2) }\end{array}$ \\
\hline \multirow{2}{*}{$\begin{array}{l}\text { Amino } \\
\text { acids }\end{array}$} & Human & \multicolumn{2}{|c|}{629} & 423 & 655 & 866 & - & 458 \\
\hline & Mouse & \multicolumn{2}{|c|}{627} & 498 & 655 & 823 & 483 & 446 \\
\hline Localization & & $\begin{array}{c}\text { Lysosome } \\
\text { /Endosome } \\
\text { PM }\end{array}$ & Extracellular & ER & $\begin{array}{l}\text { Golgi } \\
\text { PM }\end{array}$ & $\begin{array}{c}\text { ER } \\
\text { Golgi } \\
\text { PM }\end{array}$ & Mitochondria & - \\
\hline $\begin{array}{l}\text { Expression } \\
\text { (High) }\end{array}$ & & \multicolumn{2}{|c|}{ Ubiquitous } & $\begin{array}{l}\text { Ubiquitous } \\
\text { (kidney) }\end{array}$ & $\begin{array}{l}\text { Ubiquitous } \\
\text { (brain, spleen) }\end{array}$ & $\begin{array}{l}\text { Ubiquitous } \\
\text { (muscle, } \\
\text { heart) }\end{array}$ & $\begin{array}{l}\text { Ubiquitous } \\
\text { (testis, } \\
\text { pancreas, } \\
\text { brain) }\end{array}$ & Intestinal mucosa \\
\hline $\begin{array}{l}\text { Enzyme } \\
\text { Substrate/product }\end{array}$ & & \multicolumn{2}{|c|}{$\mathrm{SM} / \mathrm{Cer}$} & $\begin{array}{l}\mathrm{SM} / \mathrm{Cer} \\
\text { (in vitro) }\end{array}$ & SM/Cer & $\mathrm{SM} / \mathrm{Cer}$ & SM/Cer & SM/Cer \\
\hline Cation & & no need $\mathrm{Zn}^{2+}$ & $\mathrm{Zn}^{2+}$ & $\mathrm{Mg}^{2+}$ & $\mathrm{Mg}^{2+}$ & $\mathrm{Mg}^{2+}$ & $\mathrm{Mg}^{2+} \cdot \mathrm{Mn}^{2+}$ & Inhibition by $\mathrm{Zn}^{2+}$ \\
\hline Optimal pH & & \multicolumn{2}{|c|}{ pH 5.0} & $\mathrm{pH} 7.5$ & $\mathrm{pH} 7.5$ & $\mathrm{pH} 7.5$ & $\mathrm{pH} 7.5$ & pH 9.0 \\
\hline
\end{tabular}

Cer, Ceramide

\section{SMS}

SMS is an enzyme that catalyzes the transfer of the phosphocholine head group of phosphatidylcholine to ceramide, generating SM (Table 1). SMS family consists of three isoforms including SMS1, SMS2, and SMSr (Tafesse et al., 2006; Taniguchi and Okazaki, 2014; Yamaoka et al., 2004). The former two enzymes, but not last one, catalyze sphingomyelin synthesis, whereas all three have the activities in synthesis of the sphingomyelin analogue ceramide phosphoethanolamine even though its ability in SMS1 and SMS2 is so faint (Ding et al., 2015). SMS1 is a Golgi-resident enzyme and SMS2 is localized at plasma membrane and Golgi (Huitema et al., 2004; Tafesse et al., 2006; Taniguchi and Okazaki, 2014). SM synthesized at the Golgi is delivered to plasma membrane through the vehicle trafficking. The possible existence of SMS was shown by the enzymatic activity in the nucleus (Watanabe et al., 2004), but the precise implication of SMS and SM in the nucleus is still unclear. Plasma membrane-resident SMS2 is probably in- 
Table 3. CerS family

\begin{tabular}{|c|c|c|c|c|c|c|c|}
\hline & & CerS1 & CerS2 & CerS3 & CerS4 & CerS5 & CerS6 \\
\hline Other names & & $\begin{array}{l}\text { LASS1 } \\
\text { UOG1 }\end{array}$ & $\begin{array}{l}\text { LASS2 } \\
\text { TRH3 }\end{array}$ & $\begin{array}{l}\text { LASS3 } \\
\text { T3I }\end{array}$ & $\begin{array}{l}\text { LASS4 } \\
\text { TRH1 }\end{array}$ & $\begin{array}{l}\text { LASS5 } \\
\text { TRH4 }\end{array}$ & LASS6 \\
\hline \multirow[t]{2}{*}{$\begin{array}{l}\text { Gene symbol } \\
\text { (Locus) }\end{array}$} & Human & $\begin{array}{c}\text { CERS1 } \\
\text { (Chr.19 p12) }\end{array}$ & $\begin{array}{c}\text { CERS2 } \\
\text { (Chr.1 q21.3) }\end{array}$ & $\begin{array}{c}\text { CERS3 } \\
\text { (Chr.15 q26.3) }\end{array}$ & $\begin{array}{c}\text { CERS4 } \\
\text { (Chr.19 P13.2) }\end{array}$ & $\begin{array}{c}\text { CERS5 } \\
\text { (Chr.12 q13.12) }\end{array}$ & $\begin{array}{c}\text { CERS6 } \\
\text { (Chr.2 q24.3) }\end{array}$ \\
\hline & Mouse & $\begin{array}{c}\text { Cers1 } \\
\text { (Chr.8 E3.3) }\end{array}$ & $\begin{array}{c}\text { Cers2 } \\
\text { (Chr.3 F2) }\end{array}$ & $\begin{array}{c}\text { Cers3 } \\
\text { (Chr.7 C) }\end{array}$ & $\begin{array}{c}\text { Cers4 } \\
\text { (Chr.8 A1.2) }\end{array}$ & $\begin{array}{c}\text { Cers5 } \\
\text { (Chr.15 F1) }\end{array}$ & $\begin{array}{c}\text { Cers6 } \\
\text { (Chr.2 C2) }\end{array}$ \\
\hline \multirow[t]{2}{*}{ Amino acids } & Human & $239,337,350$ & 380 & 383,394 & 394 & 334,392 & 384,392 \\
\hline & Mouse & 350 & 380 & 419 & 393 & 414 & 384 \\
\hline Localization & & \multicolumn{6}{|c|}{ ER } \\
\hline $\begin{array}{l}\text { Expression } \\
\text { (High) }\end{array}$ & & $\begin{array}{l}\text { Brain, testis } \\
\text { skeletal muscle }\end{array}$ & Kidney, liver & Testis, skin & $\begin{array}{l}\text { Ubiquitous:low } \\
\text { (skin, heart, liver) }\end{array}$ & $\begin{array}{l}\text { Ubiquitous: } \\
\text { low }\end{array}$ & $\begin{array}{l}\text { Ubiquitous: } \\
\text { low }\end{array}$ \\
\hline $\begin{array}{l}\text { Enzyme } \\
\text { Substrate/product }\end{array}$ & & & & $\begin{array}{c}\mathrm{Sph} / \mathrm{Cer} \\
\text { (salvage pathway) }\end{array}$ & $\begin{array}{c}\mathrm{dHSph} / \mathrm{dHCer} \\
\text { (de novo synthesis) }\end{array}$ & & \\
\hline $\begin{array}{l}\text { Acyl-chain } \\
\text { length specificity }\end{array}$ & & C18 & C20-C26 & C22-C26 & $\mathrm{C} 18, \mathrm{C} 20$ & C14, C16 & C14, C16 \\
\hline $\begin{array}{l}K_{m} \text { towards } \\
\mathrm{dHSph}(\mu \mathrm{M})\end{array}$ & & $2.5 \pm 1.7$ & $4.8 \pm 0.4$ & $1.7 \pm 0.4$ & $1.8 \pm 0.4$ & $1.8 \pm 0.4$ & $2.0 \pm 0.6$ \\
\hline
\end{tabular}

Cer, Ceramide; dHCer, Dihydroceramide; dHSph, Dihydroshingosine; Sph, sphingosine

Table 4. CDase family

\begin{tabular}{|c|c|c|c|c|c|c|}
\hline & & Acid & Neutral & & Alkaline & \\
\hline Protein & & aCDase & nCDase & Alk-CDase1 & Alk-CDase2 & Alk-CDase3 \\
\hline \multirow[t]{2}{*}{$\begin{array}{l}\text { Gene symbol } \\
\text { (Locus) }\end{array}$} & Human & $\begin{array}{c}A S A H 1 \\
\text { (Chr.8 p22) }\end{array}$ & $\begin{array}{c}A S A H 2 \\
\text { (Chr.10 q11.21) }\end{array}$ & $\begin{array}{c}\text { ACER1 } \\
\text { (Chr.19 p13.3) }\end{array}$ & $\begin{array}{c}\text { ACER2 } \\
\text { (Chr.9 p22.1) }\end{array}$ & $\begin{array}{c}\text { ACER3 } \\
\text { (Chr.11 q13.5) }\end{array}$ \\
\hline & Mouse & $\begin{array}{c}\text { Asah1 } \\
\text { (Chr.8 A4) }\end{array}$ & $\begin{array}{c}\text { Asah2 } \\
\text { (Chr.19 C3) }\end{array}$ & $\begin{array}{c}\text { Acer1 } \\
\text { (Chr.17 D) }\end{array}$ & $\begin{array}{c}\text { Acer2 } \\
\text { (Chr.4 C4) }\end{array}$ & $\begin{array}{c}\text { Acer3 } \\
\text { (Chr.7 E2) }\end{array}$ \\
\hline \multirow[t]{2}{*}{ Amino acids } & Human & 389,411 & $745^{\text {short }}, 780^{\text {long }}$ & 264 & 275 & $172,230,267$ \\
\hline & Mouse & 394 & 756 & 273 & $219,229,275$ & 267 \\
\hline Localization & & Lysosome & $\begin{array}{l}\mathrm{PM}^{\text {long }} \\
\text { Mitochondria }\end{array}$ & ER & Golgi & $\begin{array}{l}\text { ER } \\
\text { Golgi }\end{array}$ \\
\hline $\begin{array}{l}\text { Expression } \\
\text { (High) }\end{array}$ & & $\begin{array}{c}\text { Kidney, lung, placenta } \\
\text { brain, Iskeltal muscle } \\
\text { (heart) }\end{array}$ & $\begin{array}{l}\text { Ubiquitous } \\
\text { (kidney, skeletal } \\
\text { muscle, } \\
\text { heart) }\end{array}$ & $\begin{array}{l}\text { Ubiquitous } \\
\text { (skin) }\end{array}$ & $\begin{array}{l}\text { Pancreas, heart } \\
\text { (placenta) }\end{array}$ & $\begin{array}{l}\text { Ubiquitous } \\
\text { (placenta) }\end{array}$ \\
\hline $\begin{array}{l}\text { Enzyme } \\
\text { Substrate/product }\end{array}$ & & Cer/Sph & Cer/Sph & Cer/Sph & Cer/Sph & Cer/Sph \\
\hline \multirow[t]{2}{*}{ Cation } & Activated & - & None & $\mathrm{Ca}^{2+}$ & $\mathrm{Ca}^{2+}$ & $\mathrm{Ca}^{2+}$ \\
\hline & Inhibited & - & None & $\mathrm{Zn}^{2+,} \mathrm{Cu}^{2+,} \mathrm{Mn}^{2+}$ & None & $\mathrm{Zn}^{2+}$ \\
\hline Optimal pH & & $\mathrm{pH} 4.5$ & $\mathrm{pH} 7.5-8.5$ & $\mathrm{pH} 8.5$ & $\mathrm{pH} 9.0$ & pH 9.5 \\
\hline
\end{tabular}

Cer, Ceramide; Sph, sphingosine

volved in turnover of the SM-ceramide cycle where SMase generates ceramide (Tani and Kuge, 2009). Whereas SMSr localizes in endoplasmic reticulum and mainly produces ceramide phosphoethanolamine (Vacaru et al., 2009). Moreover, cellular ceramide phosphoethanolamine amount is little and its function remains unknown. SMSr seems to work for maintaining ceramide balance rather than producing ceramide phosphoethanolamine.

\section{SMase}

$\mathrm{SM}$ is the most abundant in sphingolipids and constitutes microdomains at the membrane (Miyaji et al., 2005). SMase hydrolyses SM to form phosphocholine and ceramide and has been classified into three groups including acid SMase (aSMase) (Jenkins et al., 2009), alkaline SMase (Alk-SMase) (Duan, 2006) and neutral SMase (nSMase) (Airola and Hannun, 
2013; Clarke et al., 2006), according to the biochemical characteristics (Table 2). Presently, five human SMases encoded by 5 distinct genes have been cloned: aSMase (SMPD1), nSMase1 (SMPD2), nSMase2 (SMPD3), nSMase3 (SMPD4), and AlkSMase (ENPP7). MA-nSMase (smpd5) is found in mouse but not in human resides in mitochondria and its optimal $\mathrm{pH}$ is 7.5 .

\section{aSMase}

aSMase (Jenkins et al., 2009) is characterized by acidic pH optima for enzymatic activity and contributes sphingolipid catabolism. Its cDNA rises to a polypeptide of 629 amino acids. Enzymatic dysfunction of aSMase results in Niemann-Pick disease type A and B (Schulze and Sandhoff, 2011). aSMase exists as two enzymatic isoforms such a zinc-independent lysosomal aSMase and a zinc-dependent secretary aSMase. Lysosomal aSMase arises from mannose-6-phosphorylation of $\mathrm{N}$-glycans required for targeting to the endolysosomal compartments. This enzyme is predominantly localized in the endolysosomal compartments, although it has been shown to translocate to the plasma membranes in responses to stimuli (Grassme et al., 2003; Zeidan et al., 2008). Secretary aSMase is trafficked through the Golgi pathway and then extracellularly released.

\section{nSMase1}

nSMase1 was cloned by homology search of bacterial SMase as a $\mathrm{Mg}^{2+}$-dependent nSMase (Tomiuk et al., 1998) and has 423 amino acids. nSMase 1 exhibits SMase activity in vitro, but could not regulate amounts of ceramide or SM in nSMase1overexpressing cells or knockout mice (Sawai et al., 1999; Zumbansen and Stoffel, 2002). Instead of SMase activity, therefore, nSMase1 may act as phospholipase $C$ that hydrolyzes lyso-phosphatidylcholine or lyso-platelet activation factor.

\section{nSMase2}

nSMase2 (Airola and Hannun, 2013; Clarke et al., 2006) is also a $\mathrm{Mg}^{2+}$-dependent nSMase and human nSMase2 cDNA rises to a polypeptide of 655 amino acids. This enzyme containing two hydrophobic segments near the $\mathrm{N}$-terminal region is localized to the plasma membrane and Golgi apparatus. In cellbased studies, nSMase2 is well-investigated to produce ceramide in response to inflammatory cytokine or apoptosisinducing agents (Shamseddine et al., 2015).

\section{nSMase 3}

nSMase3 has been found from homology search of nSMase1 and nSMase2 (Krut et al., 2006; Moylan et al., 2014). Human nSMase 3 encodes 866 amino acids and exhibits ubiquitous expression in organs. Especially, nSMase3 strongly expresses in skeletal muscle and heart. Its enzyme is localized in endoplasmic reticulum, Golgi apparatus, and plasma membrane.

\section{MA-nSMase}

MA-nSMase has recently identified from homology search of zebrafish mitochondrial SMase in mouse, and its CDNA is translated to polypeptides of 483 amino acids (Wu et al., 2010). MA-nSMase has mitochondrial localization signal in $\mathrm{N}$-terminus and requires cations such as $\mathrm{Mg}^{2+}$ and $\mathrm{Mn}^{2+}$ for its full catalytic activity. However, human orthologue of MA-nSMase is not found yet.

\section{Alk-SMase}

Alk-SMase has 458 amino acids in human and expresses in intestine. Its enzyme has been implicated in digestion of dietary
$\mathrm{SM}$ in intestinal mucosa to produce ceramide that is further catabolized to sphingoid base (Nilsson and Duan, 2006). Moreover, Alk-SMase was shown to contribute to intestinal absorption of cholesterol (Zhang et al., 2014).

De novo ceramide synthesis

CerS (Mizutani et al., 2009; Park et al., 2014) catalyzes Nacylation of sphinganine or sphingosine at the C2-position to form dihydroceramide or ceramide, respectively. CerS activity has been firstly identified in microsome fractions (Morell and Radin, 1970). The enzyme was known to utilize a variety of fatty acyl-CoA. So far, six genes encoding mammalian CerS have been identified, named as CerS1-6, and all of which are endoplasmic reticulum-resident proteins (Table 3) (Mizutani et al., 2009; Park et al., 2014). Those CerS family enzymes display distinct substrate specificity toward carbon chain length of acyl-CoAs, although the hydroxylation and saturation status in the acyl-CoAs is unlikely to influence their specificity.

\section{CDase}

CDase catalyzes hydrolysis of ceramide to generate sphingosine (Mao and Obeid, 2008) (Table 4). According to the primary structure and the optimal $\mathrm{pH}$ in the enzymatic activity, CDase has been classified into three groups: acid CDase (aCDase) (Park and Schuchman, 2006), neutral CDase (nCDase) (Ito et al., 2014), and alkaline CDase (Alk-CDase) (Mao and Obeid, 2008). aCDase and nCDase are encoded by $A S A H 1$ and $A S A H 2$, respectively. At present, 3 distinct human Alk-CDase (Mao and Obeid, 2008) have been cloned: Alk-CDase1 (ACER1), AlkCDase2 (ACER2), and Alk-CDase3 (ACER3).

\section{aCDase}

aCDase is a lysosome-resident enzyme with a $\mathrm{pH}$ optimum of 4.5. This enzyme activity was first identified over five decade ago and is deficient in the inherited sphingolipid lysosomal storage disorder, Farber disease (Park and Schuchman, 2006). The full length human cDNA was isolated from skin fibroblasts and pituitary in 1996 (Koch et al., 1996). This aCDase is synthesized as a polypeptide of 389 amino acids ( $53 \mathrm{kDa})$, which is processed into a mature heterodimeric enzyme composed of $\alpha$ subunit (13 kDa) and highly-glycosylated $\beta$ subunit (40 kDa).

\section{nCDase}

Human nCDase activity has a $\mathrm{pH}$ optimum ranging from 7.58.5. Two isoforms of human $\mathrm{nCDase}$ have been cloned, a long form composed of 780 amino acids and a short form composed of 745 amino acids (Ito et al., 2014). The long form is predominantly localized at the plasma membrane (Hwang et al., 2005), whereas the short form appeared to be localized to mitochondria (El Bawab et al., 2000)

\section{Alk-CDase1}

Human Alk-CDase1 (Mao and Obeid, 2008) is a 264-amino acid protein with a predicted molecular weight of $31 \mathrm{kDa}$. The optimum $\mathrm{pH}$ for enzyme activation is 8.5 . It contains several putative transmembrane domains and is localized to the endoplasmic reticulum.

\section{Alk-CDase2}

Human Alk-CDase2 (Mao and Obeid, 2008) is a 275-amino acid protein with a predicted molecular weight of $31.3 \mathrm{kDa}$. The optimum $\mathrm{pH}$ for enzyme activation is 9.0 . Its protein sequence is highly homologous to Alk-CDase1 and has several transmembrane domains. This enzyme is localized to t Golgi apparatus. 


\section{Alk-CDase3}

Human Alk-CDase3 (Mao and Obeid, 2008) is a 267-amino acid protein with a predicted molecular weight of $31.6 \mathrm{kDa}$. The optimum $\mathrm{pH}$ for enzyme activation is 9.5 . Its protein sequence is also homologous to Alk-CDase1 and Alk-CDase2 and has several transmembrane domains. This enzyme is localized to the endoplasmic reticulum and Golgi apparatus.

\section{SK}

SK catalyzes phosphorylation of sphingosine to form S1P (Pitson, 2011; Pyne and Pyne, 2010). This lipid kinase exists as two isoforms, SK1 and SK2. SK1 and SK2 are encoded by different genes, respectively, SPHKL1 and SPHK2. SK1 has three splicing variants that differ only in their N-terminal, termed SK1a, SK1b, and SK1c. SK2 also has two isoforms that appear to arise from alternative start codon usage, termed SK2a and SK2b.

\section{SK1}

SK1 (Pitson, 2011; Pyne and Pyne, 2010) normally resides in the cytoplasm. A diverse of range of growth factors, cytokines and other stimuli have been shown to increase SK1 activity and induce its translocation to plasma membrane. The translocated SK1 phosphorylates sphingosine formed by nCDase catalytic action, generating S1P. Importantly, phosphorylation of SK1 at the Ser225 residue is essential for the translocation.

\section{SK2}

SK2 (Pitson, 2011; Pyne and Pyne, 2010) has nuclear localization signal in the N-terminal portion, and its subcellular localization is mainly the nucleus and cytoplasm. During cellular responses, it has been shown to be relocalized to the endoplasmic reticulum where S1P phosphatase residues. SK2 shares protein sequence similarity with SK1, although the region containing the Ser225 phosphorylation site responsible for SK1 activation is not conserved in SK2.

\section{SPPS and SPL}

\section{SPPS}

$\mathrm{S} 1 \mathrm{P}$ is generated from sphingosine by a catalytic action of SKs. Sphingosine is regenerated from S1P by the catalytic action of SPP1 and SPP2 which belong to a family of lipid phosphatases (LPPs) such as LPP1, LPP2, LPP3, the Drosophila homologues Wunen and Wunen2 (Pyne et al., 2009). SPP1 and SPP2 consist of 430 and 399 amino acids, respectively. The LPPs have broad substrate specificity in vitro and are integral membrane proteins with six transmembrane domains, while SPPs have eight transmembrane domains and show a substrate specificity that is limited to S1P, dihydroS1P and phytoS1P. SPPs are magnesium-independent and localized to the endoplasmic reticulum. The main tissue distribution of SPP1 is in kidney and placenta whereas SPP2 predominates in the heart and kidney.

\section{$S P I$}

SPL (Serra and Saba, 2010) is an enzyme that cleaves S1P to form hexadecenal and ethanolamine-phosphate. This enzymatic reaction is irreversible, thereby suggesting that SPL plays an important regulator in determining S1P levels. Human SPL is a 568-amino acid protein with a predicted molecular weight of $63.5 \mathrm{kDa}$. This protein is an integral membrane protein localized to the endoplasmic reticulum, and the active site of SPL faces the cytosolic compartment. Uniquely, SPL protein was also found in the mitochondrial-associated membrane where is associated with the mitochondria and the endoplasmic reticulum.

\section{Glucosylceramidase}

Glucosylceramidase is a $\beta$-glucosidase that catalyzes hydrolysis of glucosylceramide to form ceramide and glucose. Three types have been identified, GBA1 (Dinur et al., 1986), GBA2 (Boot et al., 2007; Yildiz et al., 2006), and GBA3 (Hayashi et al., 2007). Lysosomal GBA1 is acid $\beta$-glucosidase known as a responsible gene for Gaucher disease. This enzyme is involved in sphingolipid catabolism and also contributes to the resynthesis of ceramide through the salvage pathway. GBA2 is an endoplasmic reticulum-resident protein. GBA3, identified as a Klotho-related protein (Hayashi et al., 2007), is a cytosolic protein and its activity is insensitive to conduritol $B$ known as an inhibitor for GBA1 and GBA2. Those GBA2 and GBA3 have neutral optimal $\mathrm{pH}$ for enzyme activities.

\section{Glucosylceramide synthase (GCS)}

Glucosylceramide synthase (Bleicher and Cabot, 2002; Ishibashi et al., 2013) catalyzes the transfer of glucose residue from UDP-glucose to ceramide, generating glucosylceramide that serves as a backbone of $300-400$ glycosphingolipids. In 1996, Ichikawa et al. discovered human gene encoding GCS (Ichikawa and Hirabayashi, 1998). This enzyme is localized at Golgi apparatus where ceramide is transported by CERT from endoplasmic reticulum. Interestingly, GCS is unlikely to utilize CERT-transported ceramide for glucosylceramide synthesis, whereas SMS synthesizes SM from ceramide transported by CERT (Hanada et al., 2003; Yamaji and Hanada, 2014).

\section{ROLE OF SPHINGOLIPIDS AND METABOLIZING ENZYMES IN HEMATOLOGICAL MALIGNANCIES}

\section{Leukemia}

\section{Sphingolipids}

Ceramide

A diverse kind of anti-leukemic agents was reported to increase ceramide level in the malignant cells when the cells underwent apoptotic cell death (Carpinteiro et al., 2008; Mullen and Obeid, 2012; Saddoughi and Ogretmen, 2013). Arsenic trioxide using for the treatment of acute promyelocytic leukemia increased ceramide through the activation of de novo ceramide synthesis and the inhibition of GCS (Dbaibo et al., 2007). Instead of unsaturated ceramide, a C4-C5 saturated ceramide dihydroceramide was believed not to show cytotoxic effect in leukemia cells. A synthetic retinoid treatment was reported to induce cell death with increase of dihydroceramide in leukemia cells, but the inhibition of de novo synthesis by myriocin did not prevent the loss of cell viability even though dihyroceramide decreased (Apraiz et al., 2012). On the other hand, dihydroceramides including $\mathrm{C}_{22: 0^{-}}$and $\mathrm{C}_{24: 0^{-}}$-dihydroceramides were suggested to contribute to synthetic retinoid-induced cytotoxicity in T cell ALL CCRF-CEM cells (Holliday et al., 2013; Rodriguez-Cuenca et al., 2015). The investigation for function and regulation of dihydroceramides in the process of cell death has just begun.

A growing body of evidence suggests the involvement of ceramide in death ligand- and stress-induced apoptosis. Fas engagement by Fas ligand (FasL) induces apoptosis with ceramide increases in cancer cells. In human leukemia Jurkat cells, inhibition of SMS is proposed to facilitate Fas-induced ceramide increase resulting in caspase- 9 activation and cell death. Interestingly, caspases such as caspase-2, -7, -8 and -9 were shown to cleave and inactivate SMS1, suggesting posttranslational regulation of SMS (Lafont et al., 2010). 
When the patients in acute myeloid leukemia (AML) and chronic myeloid leukemia (CML) became resistant to chemotherapy, the activities of SMS and GCS in the chemo-resistant leukemia blasts increased higher as compared to chemosensitive ones, leading to a decrease of ceramide-dependent cell death (Itoh et al., 2003). Therefore, inhibition of SMS and/or GCS is possible therapeutics for chemotherapy-resistant hematological malignancy. Although knockout mice of GCS gene were embryonic lethal, those of SMS1 or SMS2 gene were not lethal. Considering those, specific inhibition of SMS 1 or SMS2 may be clinically valuable not to induce indiscriminate damage in indispensable tissues.

The balance between pro-apoptotic ceramide and prosurvival S1P may be important in drug-induced cell death in K562 CML cells (Baran et al., 2007). Recently in order to increase the cure rate of leukemia, there are many basic investigations to overcome the resistance to anti-cancer reagents by modulating the balance between pro-apoptotic and pro-survival sphingolipids. When acute promyelocytic leukemia-derived HL60 cells and their multidrug-resistant counterpart (HL-60/VCR cells) were treated with curcumin, firstly nSMase 2 was activated and then SMS was inhibited to make biphasic increase of ceramide generation, resulting in the overcome of the chemoresistance in HL-60/VCR cells (Shakor et al., 2014). In addition, a second generation of BCR-ABL tyrosine kinase inhibitor nilotinib was shown to up-regulate CerS and down-regulate SK1 in chemo-resistant Meg-01 CML cells (Camgoz et al., 2011). When monocytic leukemia U937 cells were treated with a combination of a Bcl-2 family inhibitors ABT-263 $(2 \mu \mathrm{M})$ and a GCS inhibitor PDMP $(45 \mu \mathrm{M})$, the synergistic effect on the induction of cell death occurred (Casson et al., 2013). CML K562/IMA cells resistant to imatinib showed the increase of cell death by the simultaneous treatment with PDMP (Baran et al., 2011). Since the concentration of PDMP used in the experiments was too high to keep its specificity for the inhibition of GCS, this combination seems to be difficult to apply to the animal experiment without investigating unknown adverse effects. Importantly, those showed clearly that the increase of ceramide enhanced cell death even in the chemo-resistant leukemia cells.

\section{Short chain ceramide and ceramide liposomes}

$D$-erythro- $N$-acetylsphingosine $\left(\mathrm{C}_{2}\right.$-ceramide $)$ was shown to inhibit the synthesis of a physiological SM due to the production of short chain SM like $\mathrm{C}_{2}-\mathrm{SM}$ and to increase physiological ceramide through acylation of sphingosine by CerS, resulting in the induction of a significant level of apoptosis in HL-60 cells (Allan, 2000; Baek et al., 2001). Short chain ceramides such as $\mathrm{C}_{2}$-ceramide and D-erythro- $N$-hexanoylsphingosine $\left(\mathrm{C}_{6}\right.$-ceramide) seem to increase long chain ceramide through recycling/salvage pathway using sphingosine backbone recycling system in KG1 leukemia cells (Chapman et al., 2010; Kitatani et al., 2008). High concentration of $\mathrm{C}_{6}$-ceramide liposomes (25 $\mu \mathrm{M}$ for $24 \mathrm{~h}$ ) induced apoptosis of natural killer leukemia cells in vitro, and systemic intravenous treatment with $\mathrm{C}_{6}$-ceramide nanoliposomes induced complete remission in the syngeneic Fischer F344 rat model of aggressive natural killer-large granular leukemia (Liu et al., 2010). Although the accumulation of $\mathrm{C}_{6^{-}}$ NBD-ceramide liposomes in the cells was suggested, the precise manner of the metabolism of nanoliposomal ceramide remains to be elucidated.

Recently the way to regulate glycolysis in cancer cells has been stressed as a target of a novel therapy for the cancer because tumor cells switch the machinery of ATP generation from TCA cycle to glycolysis as described in "Warburg effect".
Since glyceraldehyde-3-phosphate dehydrogenase is a key glycolytic enzyme, it has been emerged as a target for cancer therapy (Ganapathy-Kanniappan et al., 2013). In CLL JVM3 cells, treatment with $\mathrm{C}_{6}$-ceramide nanoliposomes was shown to promote caspase 3/7-independent necrosis by down-regulating glyceraldehyde-3-phosphate dehydrogenase and its-dependent ATP production (Ryland et al., 2013). Moreover, treatment of natural killer cell leukemia with $\mathrm{C}_{6}$-ceramide liposomes also enhanced the induction of cell death by the increase of intracellular ceramide in the presence of a GCS inhibitor 1-phenyl-2palmitoylamino-3-morpholino-1-propanol (Watters et al., 2013). It is thought that ceramides derived from incorporated liposomes are partially metabolized to glucosylceramide and the metabolic inhibition by 1-phenyl-2-palmitoylamino-3-morpholino- 1-propanol promotes the accumulation of ceramide.

\section{Short chain SM and SM liposomes}

$\mathrm{SM}$ is recognized as an important component to maintain the structure of membrane microdomain while it has been thought as a source of bioactive lipids such as ceramide and S1P. Internalization of the complex of transferrin and transferrin receptor through clathrin-coated pits were up-regulated followed by increases in cell viability, when SM-deficient $T$ lymphoid WR19L/Fas-SMS(-) cells were treated with exogenous $\mathrm{C}_{6}-\mathrm{SM}$ (Shakor et al., 2011). Those suggest the modulation of cell proliferation through SM-regulated microdomains.

The effect of SM liposomes consisting of SM has been examined on the regulation of drug pump MDR1 in human lymphoblastic leukemia CEM cells. Unexpectedly SM liposomes did not affect MDR1 activity and chemo-sensitivity in drugresistance of CEM/ADR5000 cells (Zembruski et al., 2013). Interestingly, SM contents increased in non-raft fractions, but not in raft fraction where MDR1 was distributed. It has just started investigating the role for SM lioposomes as a novel therapeutics for leukemia.

\section{S1P}

Ceramide-S1P rheostat was reported to be critical in the resistant mechanism to imatinib-induced apoptosis in K562 CML cells (Baran et al., 2007). In HL-60 cells, ceramide has been shown to promote autophagy-associated cell death by ceramide-activated protein phosphatases-dependent inactivation of mTOR, whereas S1P treatment suppressed ceramideinduced cell death by transactivation of $\mathrm{mTOR}$ via S1P receptor (S1PR) 3. Taken together, ceramide-S1P rheostat is suggested to play an important role in determining cell fates.

\section{Food components}

Withanolide $\mathrm{D}$, a pure herbal compound isolated from Withania somnifera, was reported to induce cell death in K562 and MOLT4 cells through JNK and p38 MAPK by an increase of ceramide, which was generated via nSMase (Mondal et al., 2010). Treatment with stichoposide $C$ from Thelenota anax induced apoptosis with activation of aSMase and nSMase in HL-60 cells (Yun et al., 2012). Resveratrol treatment increased expression of CerS and showed synergistic cytotoxicity with short chain ceramide, GCS inhibitor and SK1 inhibitor in K562 cells (Kartal et al., 2011). Uptake of natural compounds in hematologic cancer cells appears to promote the generation of ceramide that mediates cell death.

\section{Sphingolipids-metabolizing enzymes} SK

The inhibitor for both SK1 and SK2 named SKi was revealed to 
potentiate effects of anti-cancer agent vincristine on cell death in Jurkat and CEM-R cells (Evangelisti et al., 2014). A SK1 inhibitor BML-258 was also shown to have an inhibitory effect on cell growth in monocytic leukemia U937 and Jurkat cells (Paugh et al., 2008). Recently, SK2 inhibition by a SK2 inhibitor ABC294640 was shown to induce cell death in ALL cells (Wallington-Beddoe et al., 2014). Importantly, SK2 was uncovered to up-regulate Myc, suggesting that SK2 has an oncogenic role in ALL cells. SK inhibition by F-12509a overcame the multi-drug resistance of HL-60/Dox cells by leading the accumulation of ceramide with caspase- 3 activation and inhibition of XIAP (Bonhoure et al., 2006). Those findings are believed to raise the potential involvement of SK2 in drug resistance. Overall, further investigation seems to be indispensable for the clinical use of SK inhibitor as a leukemia therapy.

\section{SMIS}

Tricyclodecan-9-yl-xanthogenate (D609) was reported to inhibit SMS and to induce cell death of U-937 leukemia cells with an increase of ceramide and a decrease of diacylglycerol (Meng et al., 2004). The $E C_{50}$ value of D609 for $48 \mathrm{~h}$ treatment was 125 $\mu \mathrm{M}$. As this concentration was enough to inhibit other kind of enzymes such as GCS, the specificity of D609 should be taken an attention and caution should be exercised with its usage. In SMS-defected WR19L/Fas-SMS(-) lymphoid leukemia cells, overexpression of SMS1, but not SMS2, restored the deterioration of the uptake of transferrin/transferrin receptor complex through clathrin-coated pits, suggesting that SM content regulated by SMS1 in the microdomain plays a role in cell proliferation through transferrin/transferrin receptor system (Shakor et al., 2011). Overexpression of BCR-ABL in HL-60 cells upregulated SMS activity, suggesting that SMS1 is a downstream signal of BCR-ABL (Burns et al., 2013).

Defects in both SMS1 and SMS2 showed the increase of migration though the activation of CXCL12/CXCR4 axis in mouse embryonic fibroblasts, suggesting an inhibitory effect of SM on cell motility (Asano et al., 2012). The similar activation of migration was detected in SM-deficient WR19L/Fas T leukemia cells (personal communication of $\mathrm{S}$. Asano). These observations may suggest that SM plays a role in the regulatory mechanism of chemokine-induced migration.

\section{SMase}

Ceramide generation by nSMase was firstly reported as a mechanism to increase pro-apoptotic signal in leukemia cells (Hannun, 1994; Okazaki et al., 1989). Then, a diversity of experimental data has piled up to show the important function of nSMase as well as aSMase in cancer therapy (Savic and Schuchman, 2013; Shamseddine et al., 2015). Since aSMase deficiency is a key in the pathogenesis of Niemann-Pick disease, recombinant aSMase is available as a reagent for the clinical use. Recently it was shown that the combination of recombinant aSMase with a tyrosine kinase inhibitor sorafenib exhibited a synergistic effect on reducing the tumor volume and blood vessel density in Huh7 hepatocellular carcinoma xenografts (Savic et al., 2013). Unfortunately the clinical trial using recombinant aSMase or nSMase and the activator of SMases has not been performed because of the difficulty of the targeting to the malignant cells.

\section{GCS}

The inhibition of GCS has an anti-apoptotic effect because its enzyme metabolizes pro-apoptotic ceramide to glucosylceramide. GCS expression has been demonstrated to confer chemo-resistance in cancer cells (Liu et al., 1999; Senchenkov et al., 2001). Chemo-resistant leukemia blasts showed lower level of GCS as well as SMS as compared to chemo-sensitive leukemia cells (Itoh et al., 2003). As GCS is localized in cytosol portion of Golgi apparatus and MDR1 exists in the Golgi as well, the relation between MDR1 and GCS-related detoxification of ceramide in the overcome of the resistance should be considered. Inhibition of GCS by siRNA reduced the expression of MDR1 and increased rhodamine123 retention in K562/AO2 leukemia cells (Zhang et al., 2011). Those suggest that GCS expression is associated with MDR1 expression and function. In fact, GCS inhibition by 1-phenyl-2-palmitoylamino-3-morpholino-1-propanol overcame the resistance through the inhibition of MDR1 in TF-1 leukemia cells (Turzanski et al., 2005). In CML cells, GCS inhibition by PDMP promoted ceramide accumulation, resulting in the enhancement of cell death (Huang et al., 2011). It was also reported that ceramide increased by the inhibition of GCS is involved in the overcome of drug-resistance through Bcl-2 inhibition in CML cells (Baran et al., 2011; Wang et al., 2014). Although the precise mechanisms by which GCS is associated with MDR1 and the development of chemoresistance are unclear, GCS is a possible therapeutic target to overcome the chemo-resistance in hematologic malignancies.

\section{CDase}

Interferon regulatory factor 8 (IRF8) is a key transcription factor for myeloid cell differentiation and its expression is downregulated in CML cells. IRF8 was revealed to bind to the promoter region of aCDase to repress its transcription and the resistance to FasL was shown in IRF8-down-regulated CML cells probably due to the decrease of the ceramide level. Since the increase of ceramide through the inhibition of aCDase sensitized CML cells to FasL-induced apoptosis, the suppression of ceramide-induced apoptotic signal may be involved in FasL resistance of CML cells induced by the deficiency of IRF8 (Hu et al., 2011).

\section{CerS and SPT}

A tyrosine kinase inhibitor nilotinib promoted to kill human K562 and Meg-01 CML cells and its extent was correlated to the expression level of CerS genes, suggesting the involvement of nilotinib-induced inhibition of BCR-ABL in ceramide-related apoptotic signal (Camgoz et al., 2011). At present it is not known whether the activation of BCR-ABL directly inhibits ceramide generation through CerS. Recently BCR-ABL was reported to phosphorylate SPT long chain-1 (SPTLC1) at Tyr164 and repress SPT activity and ceramide synthesis (Taouji et al., 2013). Interestingly, over-expression of the mutant SPTLC1 (Tyr164 to $\mathrm{Y} 164 \mathrm{~F}$ ) increased the activity of SPT and sensitized the induction of apoptosis in K562 CML cells. Those studies might suggest that BCR-ABL promotes oncogenic activity by suppressing ceramide synthesis. Consistent with that SPTLC1 is an endoplasmic reticulum-resident protein, $\mathrm{ABL}$ was also shown to localize in endoplasmic reticulum (Qi and Mochly-Rosen, 2008).

\section{Clinical aspect of sphingolipids}

Sphingolipidomics in human blood samples have been performed. It was shown that the blood contains a large amount of $\mathrm{C}_{16}$-SM $(64 \mu \mathrm{M}), \mathrm{C}_{24}$-ceramide $(4 \mu \mathrm{M})$ and S1P $(0.68 \mu \mathrm{M}$ in serum) (Hammad et al., 2010). Serum $\mathrm{C}_{18}$-ceramide level was expected as a predictive marker for the chemotherapy with gemcitabine and doxorubicin in head and neck cancer (Saddoughi et al., 2011), but so far there is no report showing the clinical significance of sphingolipid changes in serum or plasma from leukemia patients. 


\section{Malignant lymphoma}

Sphingosine is synthesized by the hydrolysis of ceramide by CDase and has not been recognized as the main precursor of ceramide synthesis because 3-keto sphinganine is a main precursor for de novo ceramide synthesis by CerSs. However, salvage ceramide synthesis pathway from sphingosine to ceramide by CerSs is taking attention as an alternative one for ceramide synthesis in programmed cell death (Mullen et al., 2011). In the mantle cell lymphoma cell line Rec-1, the stable endocannabinoid analogue $\mathrm{R}(+)$-methanandamide increased the activities of the enzymes involved in de novo ceramide synthesis such as SPT, CerS and dihydroceramide desaturase, and inhibited ceramide metabolizing enzymes such as GCS, suggesting that cannabinoid induces cell death through proapoptotic ceramide signal (Gustafsson et al., 2009). However, the role for cannabinoid receptor types 1 and 2 in the increase of ceramide is controversial in mantle cell lymphoma cells (Gustafsson et al., 2006; 2009). Rituximab is an important reagent in immunotherapy for malignant $B$ cell lymphoma. The mechanism by which rituximab exerts its cytotoxic effect after binding to CD20 molecule remains unknown. Rituximab, which is a chimeric human immunoglobulin G1 (IgG1) anti-CD20 monoclonal antibody, induced cell cycle arrest and growth inhibition by induction of p27Kip1 with an increase of ceramide through activation of aSMase in plasma membrane microdomains (Bezombes et al., 2004). The relation between accumulation of CD20 and sphingolipids in the microdomain after treatment with rituximab was investigated (Semac et al., 2003). The effect of rituximab on malignant lymphoma cells may correlate to the expression of CD20 in the membrane microdomain regulated by GM1. CLL showed low level of GM1 while marginal zone lymphoma expressed higher GM1 level. CLL patients with a higher expression of GM1 showed higher susceptibility to rituximab-based immunotherapy, suggesting the role of GM1 in the partitioning of CD20 molecules in the microdomain (Meyer zum Buschenfelde et al., 2008). So far, the role for ceramide and $\mathrm{SM}$ in the microdomain in the effectiveness of rituximab has not been reported in malignant lymphoma cells.

\section{Multiple myeloma cells}

In Gaucher disease it is well known that multiple myeloma and $B$ cell malignancies frequently occurred (Ayto and Hughes, 2013). The GBA1-deficient mice showed the increase of glucosylceramide and glucosylsphingosine in plasma and induced the generation of $B$ cell lymphomas (11 of 21 mice) and monoclonal gammopathy (11 of 39 mice) (Pavlova et al., 2013). The precise cause of these malignancies remains to be clear, although the abnormal accumulation and deficiency of sphingolipids such as ceramide and sphingosine was pointed out.

S1P treatment up-regulated CXCL12-induced migration and adhesion of multiple myeloma cells by an increase of $\alpha 4 \beta 1$ integrin. Through CXCR4 and S1PR1, CXCL12 and S1P, respectively, activated the DOCK2-Rac1 pathway, which was required for stimulation of myeloma cell adhesion involving $\alpha 4 \beta 1$ integrin (Garcia-Bernal et al., 2013). S1P-transduced signaling inhibited dexamethasone-induced apoptosis by increasing Mcl-1 expression in multiple myeloma cell lines, which was blocked by pertussis toxin, a pan inhibitor of S1PRs ( $\mathrm{Li}$ et al., 2008). Those studies suggest that S1P-S1P receptor signal transduces adhesion and migration of multiple myeloma cells.

Epigallocatechin-3-gallate, a polyphenol extracted from green tea, has cancer chemopreventive and chemotherapeutic activities. Epigallocatechin-3-gallate induces cell cycle arrest and subsequent apoptosis through $67 \mathrm{kDa}$ laminin receptor in mul- tiple myeloma cells (Shammas et al., 2006). Tsukamoto et al. (2012) trated that ceramide generated by aSMase activation was increased in a microdomain for clustering of laminin receptor in MM cells treated with epigallocatechin-3-gallate in vitro and in vivo xenograft mouse model. Importantly, cytotoxic effects of epigallocatechin-3-gallate were confined to multiple myeloma cells and the adverse effects did not appear to occur in normal peripheral lymphocytes.

\section{ROLE OF MODULATOR OF SPHINGOLIPID FUNCTION IN HEMATOLOGICAL MALIGNANCIES}

\section{FTY720 (fingolimod)}

FTY720 is an analogue of sphingosine and phosphorylated by SK2, but not SK1. FTY720 treatment induced cell death in AML-M2 type leukemia and Kasumi cells, and also suppressed in vivo tumor growth in a Kasumi-1 cell xenograft model. Interestingly, treatment of Kasumi cells with FTY720 increased ceramide and gene expression of ceramide-generating enzymes such as GBA1, DES1, aSMase and nSMase2 (Chen et al., 2014). Moreover, pharmacological inhibition of ceramide synthase or nSMase prevented Kasumi cells from FTY720induced apoptosis. Therefore, FTY720 is suggested to induce apoptosis by promoting ceramide synthesis. Moreover, in FTY720-treated NK-cell leukemia, elevated levels of sphingosine were suggested to mediate apoptosis (Liao et al., 2011). As to the mechanism by which FTY720 treatment induces cell death in leukemia cells, the inhibition of protein phosphatase 2A (PP2A) is proposed in Kasumi-1 AML cells and Jurkat T cell leukemia cells (Matsuoka et al., 2003; Pippa et al., 2014). However, in ALL cell lines okadaic acid did not inhibit FTY-720-induced cell death regardless of inhibition of protein phosphatase $2 \mathrm{~A}$, suggesting the independent pathway of FTY-720 to induce cell death from ceramide-activated PP2A (Wallington-Beddoe et al., 2011).

FTY720 has been also implicated in autophagy induction. Wallington-Beddoe et al. (2011) demonstrated that FTY720 treatment induced cell death with an increase of LC3-II and reactive oxygen species but independently of caspases. Probably, FTY720 might serve as an inducer of autophagyassociated cell death. The pro-apoptotic proteins such as Bim and Bid were also involved in cell death of CML K562 cells with FTY720 treatment (Kiyota et al., 2013). Whereas FTY720 treatment decreased the number of malignant cells in a Bcl-2independent manner and prolonged survival time in a xenograft mouse model of Raji B cells (Liu et al., 2008). Recently, FTY720 treatment was also shown to suppress tumor growth in a xenograft mice model of $\mathrm{Ph}(+) \mathrm{ALL}$ cell lines, but not in that of $\mathrm{Ph}(-)$ ALL cells, showing selective effectiveness of FTY720 on tumor growth (Wallington-Beddoe et al., 2012). Moreover, treatment with FTY720 was shown to induce apoptosis in BCRABL-transformed myeloid precursor 32Dcl3 cells (Neviani et al., 2007). Those studies raise the potential of FTY720 as a therapeutic reagent for $\mathrm{CML}$.

Taken together, accumulating evidence suggests that FTY720 potentially serves as a chemotherapeutic reagent for hematological malignancy and the further investigations as to the mechanisms and therapeutic efficacy should be required for clinical development.

\section{S1P receptors}

It is well known that S1P stimulates lymphoid cell migration through S1PR1. The activation by CXCL12 or BCR crosslinking reduced S1PR1 expression and migratory response 
toward S1P of CLL cells isolated from patients, whereas the inhibitors of BCR-associated kinase such as Syk increased S1PR1 and migration toward S1P in CLL cells, suggesting the inhibitory effect of $\mathrm{B}$ cell activation on S1PR1 expression (Borge et al., 2014). S1PR2-deficient mice generated the tumor with the features of germinal center-derived diffuse large $B$ cell lymphoma and 28 of $106(26 \%)$ diffuse large B cell lymphoma patients harbored the multiple somatic mutations in the $5^{\prime}$ sequences of the S1PR2 gene (Cattoretti et al., 2009). In the KM$\mathrm{H} 2$ and SUP-HD1 Hodgkin lymphoma cells, the increase of their migration by S1P treatment was blocked by S1PR1 antagonists VPC44116 and FTY720-P. A subset of Hodgkin lymphoma cases $(7 / 57,12 \%)$ showed strong, membranous staining for S1PR1, suggesting the therapeutic potential of S1PR inhibitor for infiltration of Hodgkin lymphoma cells in some cases (Kluk et al., 2013). Immunohistochemistry of S1PR1 in clinical samples showed the strong expression in the lymph node (19 out of 19), gastrointestinal tract (10 out of 10), bone marrow (9 out of 9 ), and orbita (1 out of 1 ) of mantle cell lymphoma patients (Nishimura et al., 2010). The role of S1PR1 was opposite to that of S1PR2 in the regulation of lymphoid cell proliferation. The precise biological implications of S1PRs in survival/proliferation of lymphoid cells should be clarified in the future.

\section{CONCLUSIONS}

Sphingolipids such as ceramide and S1P have been recognized as bioactive lipids in cell death and proliferation/survival. In this review we overviewed role for sphingolipids in the induction of cell death in several types of hematological malignancies such as leukemia, malignant lymphoma and multiple myeloma. The main backbone molecule of sphingolipid network is ceramide. Ceramide is synthesized from serine and fatty acids with different kinds of carbon chains by de novo ceramide pathway in endoplasmic reticulum, and transferred to the Golgi apparatus by CERT for synthesis of SM by SMS while ceramide transfer protein for glucosylceramide to Golgi apparatus remains unknown. Sphingosine generated by CDase is phosphorylated and turns to S1P by SK1 or SK2. The complex sphingolipids such as glucosylceramide and GM3 are transferred to the micro-organelles to exert their functions and again returned to ceramide by salvage pathway. Likely, the catabolized sphingolipids such as sphingosine and sphingadienine are possibly resynthesized to ceramide by CerSs. Thus, it is critical to consider the difference of molecular species in active sphingolipids and the variation of time and localization in sphingolipid metabolism to understand the bona fide role of pathobiological sphingolipids in the cells. For example, curcumininduced HL-60 apoptosis showed two phase-increases of ceramide accumulation by the activation of nSMase and subsequent inhibition of SMS, suggesting that each increase of ceramide plays a role in a different time course and localization in the process of cell death (Shakor et al., 2014). We have recently reported (1) the important role of SM in the microdomain of plasma membrane in transferrin-induced lymphoid cell proliferation and CXCL12-induced cell migration, (2) the positive role of ceramide in the nucleus in Fas-induced cell death even though the existence of sphingolipid metabolizing enzymes in the nucleus remains clarified and (3) the competitive role of ceramide and S1P in the cytosol in the regulation of mTOR in the process of autophagy (Taniguchi et al., 2012). In addition, although SK1 and SK2 both generate S1P, SK1 resides in the cytosol and moves to the near site of plasma membrane but SK2 locates in the nucleus (Siow and Wattenberg, 2011). SK1 is involved in cell proliferation while SK2 plays a role in apoptotic cell death. The lipids exist as a structurally different form in the cells such as a vesicular micelle, a component of the membrane microdomain and a proteinbinding form. Thus, it remains to clarify the precise implications of the vesicular and non-vesicular trafficking, and the membrane topology of sphingolipids in the regulation of cell death and proliferation/survival. Taken together, these findings suggest that a diverse bioactive sphingolipids play a role in many cell functions at the different time, different form and intracellular components and that these dysregulation of sphingolipids may be closely related to the causes in human disorders.

To develop a novel therapeutics for hematological malignancies we have to investigate the role of sphingolipids: (1) as an intracellular signaling molecule (ceramide, S1P and FTY720) and a regulator of microdomain to control trans-membrane receptor (SM and S1P receptor), (2) as a homeostatic keeper of the bioactive vesicles such as recycling and degradation endosomes, autophagosomes and lysosomes (SM, ceramide and $\mathrm{S1P}$ ) and (3) as an regulator of intercellular communicator like exosomes and ectosomes (SM, ceramide and S1P). In the future, we hope that the research, which clarifies the regulation of bioactive sphingolipid functions in not only the cells but also the animal models and human disorders, brings about a novel and effective sphingolipid-targeting therapy in hematological malignancies different from the recently on-going chemo-, radio- or immunotherapy.

\section{ACKNOWLEDGMENTS}

This work was partly supported by: the Takeda Science Foundation (2012); a joint research project with Sharome Co., Ltd. (20122015); ONO Pharmaceutical Co., Ltd. (2012-2014); the JSPS KAKENHI (Grant Number 21890144 (to KK) and 25870853 (to MT)); a grant from Strategic Research Foundation Grant-aided Project for Private Universities from Ministry of Education, Culture, Sport, Science, and Technology (MEXT) (No. S1201004; H201216); SENSHIN Medical Research Foundation; Mizutani Foundation for Glycoscience (2013-14); the Collaborative Research from Kanazawa Medical University (C2012-4, C2013-1). We are grateful to Dr. Satoshi Asano (Hiroshima University), Dr. Abo Bakr Abdel Shakor (King Khalid University), and Dr. Mayumi Hashimoto-Nishimura to complete this work.

\section{REFERENCES}

Adada, M., Canals, D., Hannun, Y.A., and Obeid, L.M. (2014) Sphingolipid regulation of ezrin, radixin, and moesin proteins family: implications for cell dynamics. Biochim. Biophys. Acta 1841, 727-737.

Airola, M.V., and Hannun, Y.A. (2013). Sphingolipid metabolism and neutral sphingomyelinases. Handb. Exp. Pharmacol. 2013, 57-76.

Allan, D. (2000). Lipid metabolic changes caused by short-chain ceramides and the connection with apoptosis. Biochem. J. 345 Pt 3, 603-610

Apraiz, A., Idkowiak-Baldys, J., Nieto-Rementeria, N., Boyano, M.D., Hannun, Y.A., and Asumendi, A. (2012). Dihydroceramide accumulation and reactive oxygen species are distinct and nonessential events in 4-HPR-mediated leukemia cell death. Biochem. Cell Biol. 90, 209-223.

Asano, S., Kitatani, K., Taniguchi, M., Hashimoto, M., Zama, K Mitsutake, S., Igarashi, Y., Takeya, H., Kigawa, J., Hayashi, A., et al. (2012). Regulation of cell migration by sphingomyelin synthases: sphingomyelin in lipid rafts decreases responsiveness to signaling by the CXCL12/CXCR4 pathway. Mol. Cell. Biol. 32, 3242-3252.

Ayto, R., and Hughes, D.A. (2013). Gaucher disease and myeloma Crit Rev. Oncog. 18, 247-268.

Baek, M.Y., Yoo, H.S., Nakaya, K., Moon, D.C., and Lee, Y.M. (2001). Sphingolipid metabolic changes during chiral C2- 
ceramides induced apoptosis in human leukemia cells. Arch Pharm. Res. 24, 144-149.

Baran, Y., Salas, A., Senkal, C.E., Gunduz, U., Bielawski, J., Obeid L.M., and Ogretmen, B. (2007). Alterations of ceramide/ sphingosine 1-phosphate rheostat involved in the regulation of resistance to imatinib-induced apoptosis in K562 human chronic myeloid leukemia cells. J. Biol. Chem. 282, 10922-10934.

Baran, Y., Bielawski, J., Gunduz, U., and Ogretmen, B. (2011). Targeting glucosylceramide synthase sensitizes imatinib-resistan chronic myeloid leukemia cells via endogenous ceramide accumulation. J Cancer Res. Clin. Oncol. 137, 1535-1544.

Bezombes, C., Grazide, S., Garret, C., Fabre, C., Quillet-Mary, A. Muller, S., Jaffrezou, J.P., and Laurent, G. (2004). Rituximab antiproliferative effect in B-lymphoma cells is associated with acid-sphingomyelinase activation in raft microdomains. Blood 104, 1166-1173.

Bleicher, R.J., and Cabot, M.C. (2002). Glucosylceramide synthase and apoptosis. Biochim. Biophys. Acta 1585, 172-178.

Bonhoure, E., Pchejetski, D., Aouali, N., Morjani, H., Levade, T., Kohama, T., and Cuvillier, O. (2006). Overcoming MDRassociated chemoresistance in HL-60 acute myeloid leukemia cells by targeting sphingosine kinase-1. Leukemia 20, 95-102.

Boot, R.G., Verhoek, M., Donker-Koopman, W., Strijland, A., van Marle, J., Overkleeft, H.S., Wennekes, T., and Aerts, J.M. (2007). Identification of the non-lysosomal glucosylceramidase as beta-glucosidase 2. J. Biol. Chem. 282, 1305-1312.

Borge, M., Remes Lenicov, F., Nannini, P.R., de los Rios Alicandu, M.M., Podaza, E., Ceballos, A., Fernandez Grecco, H., Cabrejo M., Bezares, R.F., Morande, P.E., et al. (2014). The expression of sphingosine-1 phosphate receptor-1 in chronic lymphocytic leukemia cells is impaired by tumor microenvironmental signals and enhanced by piceatannol and R406. J. Immunol. 193, 31653174

Burns, T.A., Subathra, M., Signorelli, P., Choi, Y., Yang, X., Wang, Y., Villani, M., Bhalla, K., Zhou, D., and Luberto, C. (2013) Sphingomyelin synthase 1 activity is regulated by the BCR-ABL oncogene. J. Lipid Res. 54, 794-805.

Camgoz, A., Gencer, E.B., Ural, A.U., Avcu, F and Baran, Y. (2011). Roles of ceramide synthase and ceramide clearence genes in nilotinib-induced cell death in chronic myeloid leukemia cells. Leuk. Lymphoma 52, 1574-1584.

Carpinteiro, A., Dumitru, C., Schenck, M., and Gulbins, E. (2008) Ceramide-induced cell death in malignant cells. Cancer Lett 264, 1-10.

Casson, L., Howell, L., Mathews, L.A., Ferrer, M., Southall, N., Guha, R., Keller, J.M., Thomas, C., Siskind, L.J., and Beverly, L.J. (2013). Inhibition of ceramide metabolism sensitizes human leukemia cells to inhibition of BCL2-like proteins. PLoS One 8 e54525.

Cattoretti, G., Mandelbaum, J., Lee, N., Chaves, A.H., Mahler, A.M., Chadburn, A., Dalla-Favera, R., Pasqualucci, L., and MacLennan, A.J. (2009). Targeted disruption of the S1P2 sphingosine 1phosphate receptor gene leads to diffuse large B-cell lymphoma formation. Cancer Res. 69, 8686-8692.

Chapman, J.V., Gouaze-Andersson, V., Messner, M.C., Flowers, M., Karimi, R., Kester, M., Barth, B.M., Liu, X., Liu, Y.Y., Giuliano, A.E., et al. (2010). Metabolism of short-chain ceramide by human cancer cells--implications for therapeutic approaches. Biochem. Pharmacol. 80, 308-315.

Chen, L., Luo, L.F., Lu, J., Li, L., Liu, Y.F., Wang, J., Liu, H., Song H., Jiang, H., Chen, S.J., et al. (2014). FTY720 induces apoptosis of M2 subtype acute myeloid leukemia cells by targeting sphingolipid metabolism and increasing endogenous ceramide levels. PLoS One 9, e103033.

Clarke, C.J., Snook, C.F., Tani, M., Matmati, N., Marchesini, N., and Hannun, Y.A. (2006). The extended family of neutral sphingomyelinases. Biochemistry 45, 11247-11256.

Dbaibo, G.S., Kfoury, Y., Darwiche, N., Panjarian, S., Kozhaya, L., Nasr, R., Abdallah, M., Hermine, O., El-Sabban, M., de The, H., et al. (2007). Arsenic trioxide induces accumulation of cytotoxic levels of ceramide in acute promyelocytic leukemia and adult Tcell leukemia/lymphoma cells through de novo ceramide synthesis and inhibition of glucosylceramide synthase activity. Haematologica 92, 753-762.

Degagne, E., and Saba, J.D. (2014). S1pping fire: Sphingosine-1phosphate signaling as an emerging target in inflammatory bowel disease and colitis-associated cancer. Clin. Exp. Gastroenterol. 7, 205-214.

Ding, T., Kabir, I., Li, Y., Lou, C., Yazdanyar, A., Xu, J., Dong, J. Zhou, H., Park, T., Boutjdir, M., et al. (2015). All members in the sphingomyelin synthase gene family have ceramide pho- sphoethanolamine synthase activity. J. Lipid Res. 56, 537-545

Dinur, T., Osiecki, K.M., Legler, G., Gatt, S., Desnick, R.J., and Grabowski, G.A. (1986). Human acid beta-glucosidase: isolation and amino acid sequence of a peptide containing the catalytic site. Proc. Natl. Acad. Sci. USA 83, 1660-1664

Duan, R.D. (2006). Alkaline sphingomyelinase: an old enzyme with novel implications. Biochim. Biophys. Acta 1761, 281-291.

El Bawab, S., Roddy, P., Qian, T., Bielawska, A., Lemasters, J.J., and Hannun, Y.A. (2000). Molecular cloning and characterization of a human mitochondrial ceramidase. J. Biol. Chem. 275, 21508-21513.

Evangelisti, C., Evangelisti, C., Teti, G., Chiarini, F., Falconi, M. Melchionda, F., Pession, A., Bertaina, A., Locatelli, F., McCubrey, J.A., et al. (2014). Assessment of the effect of sphingosine kinase inhibitors on apoptosis,unfolded protein response and autophagy of T-cell acute lymphoblastic leukemia cells; indications for novel therapeutics. Oncotarget 5, 7886-7901.

Futerman, A.H., and Hannun, Y.A. (2004). The complex life of simple sphingolipids. EMBO Rep. 5, 777-782.

Futerman, A.H., and Riezman, H. (2005). The ins and outs of sphingolipid synthesis. Trends Cell Biol. 15, 312-318.

Ganapathy-Kanniappan, S., Kunjithapatham, R., and Geschwind, J.F. (2013). Anticancer efficacy of the metabolic blocker 3-bromopyruvate: specific molecular targeting. Anticancer Res. 33, 13-20.

Garcia-Bernal, D., Redondo-Munoz, J., Dios-Esponera, A., Chevre, R., Bailon, E., Garayoa, M., Arellano-Sanchez, N., Gutierrez, N.C., Hidalgo, A., Garcia-Pardo, A., et al. (2013). Sphingosine-1phosphate activates chemokine-promoted myeloma cell adhesion and migration involving alpha4beta1 integrin function. J. Pathol. 229, 36-48.

Gault, C.R., Obeid, L.M., and Hannun, Y.A. (2010). An overview of sphingolipid metabolism: from synthesis to breakdown. Adv. Exp. Med. Biol. 688, 1-23.

Grabowski, G.A. (1993). Gaucher disease. Enzymology, genetics, and treatment. Adv. Hum. Genet. 21, 377-441.

Grassme, H., Jendrossek, V., Riehle, A., von Kurthy, G., Berger, J., Schwarz, H., Weller, M., Kolesnick, R., and Gulbins, E. (2003). Host defense against Pseudomonas aeruginosa requires ceramide-rich membrane rafts. Nat. Med. 9, 322-330.

Gustafsson, K., Christensson, B., Sander, B., and Flygare, J. (2006). Cannabinoid receptor-mediated apoptosis induced by $\mathrm{R}(+)$ methanandamide and Win55,212-2 is associated with ceramide accumulation and p38 activation in mantle cell lymphoma. Mol. Pharmacol. 70, 1612-1620.

Gustafsson, K., Sander, B., Bielawski, J., Hannun, Y.A., and Flygare, J. (2009). Potentiation of cannabinoid-induced cytotoxicity in mantle cell lymphoma through modulation of ceramide metabolism. Mol. Cancer Res. 7, 1086-1098.

Hammad, S.M., Pierce, J.S., Soodavar, F., Smith, K.J., Al Gadban, M.M., Rembiesa, B., Klein, R.L., Hannun, Y.A., Bielawski, J., and Bielawska, A. (2010). Blood sphingolipidomics in healthy humans: impact of sample collection methodology. J. Lipid Res. 51, 3074-3087.

Hanada, K. (2003). Serine palmitoyltransferase, a key enzyme of sphingolipid metabolism. Biochim. Biophys. Acta 1632, 16-30.

Hanada, K., Hara, T., and Nishijima, M. (2000). Purification of the serine palmitoyltransferase complex responsible for sphingoid base synthesis by using affinity peptide chromatography techniques. J. Biol. Chem. 275, 8409-8415.

Hanada, K., Kumagai, K., Yasuda, S., Miura, Y., Kawano, M., Fukasawa, M., and Nishijima, M. (2003). Molecular machinery for non-vesicular trafficking of ceramide. Nature 426, 803-809.

Hannun, Y.A. (1994). The sphingomyelin cycle and the second messenger function of ceramide. J. Biol. Chem. 269, 3125-3128.

Hayashi, $Y$, Okino, N Kakuta, $Y$, Shikanai, T. Tani, M. Narimatsu, H., and Ito, M. (2007). Klotho-related protein is novel cytosolic neutral beta-glycosylceramidase. J. Biol. Chem. 282, 30889-30900.

Holliday, M.W., Jr., Cox, S.B., Kang, M.H., and Maurer, B.J. (2013). C22:0- and C24:0-dihydroceramides confer mixed cytotoxicity in T-cell acute lymphoblastic leukemia cell lines. PLoS One 8 e74768.

Hu, X., Yang, D., Zimmerman, M., Liu, F., Yang, J., Kannan, S. Burchert, A., Szulc, Z., Bielawska, A., Ozato, K., et al. (2011) IRF8 regulates acid ceramidase expression to mediate apoptosis and suppresses myelogeneous leukemia. Cancer Res. 71, 2882-2891.

Huang, W.C., Tsai, C.C., Chen, C.L., Chen, T.Y., Chen, Y.P., Lin Y.S., Lu, P.J., Lin, C.M., Wang, S.H., Tsao, C.W., et al. (2011). Glucosylceramide synthase inhibitor PDMP sensitizes chronic myeloid leukemia T315I mutant to Bcr-Abl inhibitor and coopera- 
tively induces glycogen synthase kinase-3-regulated apoptosis. FASEB J. 25, 3661-3673.

Huitema, K., van den Dikkenberg, J., Brouwers, J.F., and Holthuis, J.C. (2004). Identification of a family of animal sphingomyelin synthases. EMBO J. 23, 33-44.

Hwang, Y.H., Tani, M., Nakagawa, T., Okino, N., and Ito, M. (2005) Subcellular localization of human neutral ceramidase expressed in HEK293 cells. Biochem. Biophys. Res. Commun. 331, 37-42.

Ichikawa, S., and Hirabayashi, Y. (1998). Glucosylceramide synthase and glycosphingolipid synthesis. Trends Cell Biol. 8, 198202.

Ishibashi, Y., Kohyama-Koganeya, A., and Hirabayashi, Y. (2013). New insights on glucosylated lipids: metabolism and functions. Biochim. Biophys. Acta 1831, 1475-1485.

Ito, M., Okino, N., and Tani, M. (2014). New insight into the structure, reaction mechanism, and biological functions of neutral ceramidase. Biochim. Biophys. Acta 1841, 682-691.

Itoh, M., Kitano, T., Watanabe, M., Kondo, T., Yabu, T., Taguchi, Y. Iwai, K., Tashima, M., Uchiyama, T., and Okazaki, T. (2003) Possible role of ceramide as an indicator of chemoresistance: decrease of the ceramide content via activation of glucosylceramide synthase and sphingomyelin synthase in chemoresistant leukemia. Clin. Cancer Res. 9, 415-423.

Jenkins, R.W., Canals, D., and Hannun, Y.A. (2009). Roles and regulation of secretory and lysosomal acid sphingomyelinase. Cell. Signal. 21, 836-846.

Kartal, M., Saydam, G., Sahin, F., and Baran, Y. (2011). Resveratrol triggers apoptosis through regulating ceramide metabolizing genes in human K562 chronic myeloid leukemia cells. Nutr. Cancer 63, 637-644.

Kitatani, K., Idkowiak-Baldys, J., and Hannun, Y.A. (2008). The sphingolipid salvage pathway in ceramide metabolism and signaling. Cell. Signal. 20, 1010-1018.

Kiyota, M., Kuroda, J., Yamamoto-Sugitani, M., Shimura, Y., Nakayama, R., Nagoshi, H., Mizutani, S., Chinen, Y., Sasaki, N., Sakamoto, N., et al. (2013). FTY720 induces apoptosis of chronic myelogenous leukemia cells via dual activation of BIM and BID and overcomes various types of resistance to tyrosine kinase inhibitors. Apoptosis 18, 1437-1446.

Kluk, M.J., Ryan, K.P., Wang, B., Zhang, G., Rodig, S.J., and Sanchez, T. (2013). Sphingosine-1-phosphate receptor 1 in classical Hodgkin lymphoma: assessment of expression and role in cell migration. Lab. Invest. 93, 462-471.

Koch, J., Gartner, S., Li, C.M., Quintern, L.E., Bernardo, K., Levran O. Schnabel, D., Desnick, R.J., Schuchman, E.H., and Sandhoff, K. (1996). Molecular cloning and characterization of a full-length complementary DNA encoding human acid ceramidase. Identification Of the first molecular lesion causing Farber disease. J. Biol. Chem. 271, 33110-33115.

Krut, O., Wiegmann, K., Kashkar, H., Yazdanpanah, B., and Kronke, M. (2006). Novel tumor necrosis factor-responsive mammalian neutral sphingomyelinase-3 is a C-tail-anchored protein. J. Biol. Chem. 281, 13784-13793.

Lafont, E., Milhas, D., Carpentier, S., Garcia, V., Jin, Z.X., Umehara, H., Okazaki, T., Schulze-Osthoff, K., Levade, T., Benoist, H., et al. (2010). Caspase-mediated inhibition of sphingomyelin synthesis is involved in FasL-triggered cell death. Cell Death Differ 17, 642-654

Li, Q.F., Wu, C.T., Guo, Q., Wang, H., and Wang, L.S. (2008) Sphingosine 1-phosphate induces Mcl-1 upregulation and protects multiple myeloma cells against apoptosis. Biochem. Biophys. Res. Commun. 371, 159-162.

Liao, A., Broeg, K., Fox, T., Tan, S.F., Watters, R., Shah, M.V., Zhang, L.Q., Li, Y., Ryland, L., Yang, J., et al. (2011). Therapeutic efficacy of FTY720 in a rat model of NK-cell leukemia. Blood $118,2793-2800$

Liu, Y.Y., Han, T.Y., Giuliano, A.E., and Cabot, M.C. (1999). Expression of glucosylceramide synthase, converting ceramide to glucosylceramide, confers adriamycin resistance in human breast cancer cells. J. Biol. Chem. 274, 1140-1146.

Liu, Q., Zhao, X., Frissora, F., Ma, Y., Santhanam, R., Jarjoura, D., Lehman, A., Perrotti, D., Chen, C.S., Dalton, J.T., et al. (2008). FTY720 demonstrates promising preclinical activity for chronic lymphocytic leukemia and lymphoblastic leukemia/lymphoma. Blood 111, 275-284.

Liu, X., Ryland, L., Yang, J., Liao, A., Aliaga, C., Watts, R., Tan, S.F., Kaiser, J., Shanmugavelandy, S.S., Rogers, A., et al (2010). Targeting of survivin by nanoliposomal ceramide induces complete remission in a rat model of NK-LGL leukemia. Blood 116, 4192-4201.

Maceyka, M., and Spiegel, S. (2014). Sphingolipid metabolites in inflammatory disease. Nature 510, 58-67.

Mao, C., and Obeid, L.M. (2008). Ceramidases: regulators of cellular responses mediated by ceramide, sphingosine, and sphingosine-1-phosphate. Biochim. Biophys. Acta 1781, 424434.

Matsuoka, Y., Nagahara, Y., Ikekita, M., and Shinomiya, T. (2003). A novel immunosuppressive agent FTY720 induced Akt dephosphorylation in leukemia cells. Br. J. Pharmacol. 138, 1303-1312.

Meng, A., Luberto, C., Meier, P., Bai, A., Yang, X., Hannun, Y.A and Zhou, D. (2004). Sphingomyelin synthase as a potential target for D609-induced apoptosis in U937 human monocytic leukemia cells. Exp. Cell Res. 292, 385-392.

Meyer zum Buschenfelde, C., Feuerstacke, Y., Gotze, K.S., Scholze, K., and Peschel, C. (2008). GM1 expression of nonHodgkin's lymphoma determines susceptibility to rituximab treatment. Cancer Res. 68, 5414-5422.

Miyaji, M., Jin, Z.X., Yamaoka, S., Amakawa, R., Fukuhara, S., Sato, S.B., Kobayashi, T., Domae, N., Mimori, T., Bloom, E.T., et al. (2005). Role of membrane sphingomyelin and ceramide in platform formation for Fas-mediated apoptosis. J. Exp. Med. 202, 249-259.

Mizutani, Y., Mitsutake, S., Tsuji, K., Kihara, A., and Igarashi, Y. (2009). Ceramide biosynthesis in keratinocyte and its role in skin function. Biochimie 91, 784-790.

Mondal, S., Mandal, C., Sangwan, R., Chandra, S., and Mandal, C. (2010). Withanolide D induces apoptosis in leukemia by targeting the activation of neutral sphingomyelinase-ceramide cascade mediated by synergistic activation of c-Jun $\mathrm{N}$-terminal kinase and p38 mitogen-activated protein kinase. Mol. Cancer 9, 239.

Morell, P., and Radin, N.S. (1970). Specificity in ceramide biosynthesis from long chain bases and various fatty acyl coenzyme A's by brain microsomes. J. Biol. Chem. 245, 342-350.

Moylan, J.S., Smith, J.D., Wolf Horrell, E.M., McLean, J.B. Deevska, G.M., Bonnell, M.R., Nikolova-Karakashian, M.N., and Reid, M.B. (2014). Neutral sphingomyelinase-3 mediates TNFstimulated oxidant activity in skeletal muscle. Redox Biol. 2, 910920.

Mullen, T.D., Jenkins, R.W., Clarke, C.J., Bielawski, J., Hannun, Y.A., and Obeid, L.M. (2011). Ceramide synthase-dependent ceramide generation and programmed cell death: involvement of salvage pathway in regulating postmitochondrial events. $\mathrm{J}$. Biol. Chem. 286, 15929-15942.

Mullen, T.D., and Obeid, L.M. (2012). Ceramide and apoptosis: exploring the enigmatic connections between sphingolipid metabolism and programmed cell death. Anticancer Agents Med. Chem. 12, 340-363.

Neviani, P., Santhanam, R., Oaks, J.J., Eiring, A.M., Notari, M., Blaser, B.W., Liu, S., Trotta, R., Muthusamy, N., GambacortiPasserini, C., et al. (2007). FTY720, a new alternative for treating blast crisis chronic myelogenous leukemia and Philadelphia chromosome-positive acute lymphocytic leukemia. J. Clin. Invest. 117, 2408-2421.

Nilsson, A and Duan, R.D. (2006). Absorption and lipoprotein transport of sphingomyelin. J. Lipid Res. 47, 154-171.

Nishimura, H., Akiyama, T., Monobe, Y., Matsubara, K., Igarashi, Y., Abe, M., Sugihara, T., and Sadahira, Y. (2010). Expression of sphingosine-1-phosphate receptor 1 in mantle cell lymphoma. Mod. Pathol. 23, 439-449.

Obeid, L.M., Linardic, C.M., Karolak, L.A., and Hannun, Y.A. (1993) Programmed cell death induced by ceramide. Science 259, 1769-1771.

Okazaki, T., Bell, R.M., and Hannun, Y.A. (1989). Sphingomyelin turnover induced by vitamin D3 in HL-60 cells. Role in cell differentiation. J. Biol. Chem. 264, 19076-19080.

Park, J.H., and Schuchman, E.H. (2006). Acid ceramidase and human disease. Biochim. Biophys. Acta 1758, 2133-2138.

Park, J.W., Park, W.J., and Futerman, A.H. (2014). Ceramide synthases as potential targets for therapeutic intervention in human diseases. Biochim. Biophys. Acta 1841, 671-681.

Paugh, S.W., Paugh, B.S., Rahmani, M., Kapitonov, D., Almenara J.A., Kordula, T., Milstien, S., Adams, J.K., Zipkin, R.E., Grant, $\mathrm{S}$., et al. (2008). A selective sphingosine kinase 1 inhibitor integrates multiple molecular therapeutic targets in human leukemia. Blood 112, 1382-1391.

Pavlova, E.V., Wang, S.Z., Archer, J., Dekker, N., Aerts, J.M., Karlsson, S., and Cox, T.M. (2013). B cell lymphoma and myeloma in murine Gaucher's disease. J. Pathol. 231, 88-97.

Pippa, R., Dominguez, A., Christensen, D.J., Moreno-Miralles, I., Blanco-Prieto, M.J., Vitek, M.P., and Odero, M.D. (2014). Effect 
of FTY720 on the SET-PP2A complex in acute myeloid leukemia; SET binding drugs have antagonistic activity. Leukemia 28 1915-1918.

Pitson, S.M. (2011). Regulation of sphingosine kinase and sphingolipid signaling. Trends Biochem. Sci. 36, 97-107.

Pyne, N.J., and Pyne, S. (2010). Sphingosine 1-phosphate and cancer. Nat. Rev. Cancer 10, 489-503.

Pyne, S., Lee, S.C., Long, J., and Pyne, N.J. (2009). Role of sphingosine kinases and lipid phosphate phosphatases in regulating spatial sphingosine 1-phosphate signalling in health and disease. Cell. Signal. 21, 14-21.

Qi, X., and Mochly-Rosen, D. (2008). The PKCdelta -Abl complex communicates ER stress to the mitochondria - an essential step in subsequent apoptosis. J. Cell Sci. 121, 804-813.

Rodriguez-Cuenca, S., Barbarroja, N., and Vidal-Puig, A. (2015) Dihydroceramide desaturase 1, the gatekeeper of ceramide induced lipotoxicity. Biochim. Biophys. Acta 1851, 40-50.

Ryland, L.K., Doshi, U.A., Shanmugavelandy, S.S., Fox, T.E., Aliaga, C., Broeg, K., Baab, K.T., Young, M., Khan, O., Haakenson, J.K., et al. (2013). C6-ceramide nanoliposomes target the Warburg effect in chronic lymphocytic leukemia. PLoS One 8, e84648.

Saba, J.D., and de la Garza-Rodea, A.S. (2013). S1P lyase in skeletal muscle regeneration and satellite cell activation: exposing the hidden lyase. Biochim Biophys Acta 1831, 167-175.

Saddoughi, S.A., Garrett-Mayer, E., Chaudhary, U., O'Brien, P.E., Afrin, L.B., Day, T.A., Gillespie, M.B., Sharma, A.K., Wilhoit, C.S., Bostick, R., et al. (2011). Results of a phase II trial of gemcitabine plus doxorubicin in patients with recurrent head and neck cancers: serum C(1)(8)-ceramide as a novel biomarker for monitoring response. Clin. Cancer Res. 17, 6097-6105.

Saddoughi, S.A., and Ogretmen, B. (2013). Diverse functions of ceramide in cancer cell death and proliferation. Adv. Cancer Res. 117, 37-58.

Savic, R., He, X., Fiel, I., and Schuchman, E.H. (2013). Recombinant human acid sphingomyelinase as an adjuvant to sorafenib treatment of experimental liver cancer. PLoS One 8, e65620.

Savic, R., and Schuchman, E.H. (2013). Use of acid sphingomyelinase for cancer therapy. Adv. Cancer Res. 117, 91-115.

Sawai, H., Domae, N., Nagan, N., and Hannun, Y.A. (1999). Function of the cloned putative neutral sphingomyelinase as lysoplatelet activating factor-phospholipase C. J. Biol. Chem. 274 38131-38139.

Schulze, H., and Sandhoff, K. (2011). Lysosomal lipid storage diseases. Cold Spring Harb Perspect Biol. 3.

Semac, I., Palomba, C., Kulangara, K., Klages, N., van EchtenDeckert, G., Borisch, B., and Hoessli, D.C. (2003). Anti-CD20 therapeutic antibody rituximab modifies the functional organization of rafts/microdomains of B lymphoma cells. Cancer Res. 63 534-540.

Senchenkov, A., Litvak, D.A., and Cabot, M.C. (2001). Targeting ceramide metabolism--a strategy for overcoming drug resistance. J. Natl. Cancer Inst. 93, 347-357.

Serra, M., and Saba, J.D. (2010). Sphingosine 1-phosphate lyase, a key regulator of sphingosine 1-phosphate signaling and function. Adv. Enzyme Regul. 50, 349-362.

Shakor, A.B., Taniguchi, M., Kitatani, K., Hashimoto, M., Asano, S. Hayashi, A., Nomura, K., Bielawski, J., Bielawska, A., Watanabe, K., et al. (2011). Sphingomyelin synthase 1-generated sphingomyelin plays an important role in transferrin trafficking and cell proliferation. J. Biol. Chem. 286, 36053-36062.

Shakor, A.B., Atia, M., Ismail, I.A., Alshehri, A., El-Refaey, H., Kwiatkowska, K., and Sobota, A. (2014). Curcumin induces apoptosis of multidrug-resistant human leukemia HL60 cells by complex pathways leading to ceramide accumulation. Biochim. Biophys. Acta 1841, 1672-1682.

Shammas, M.A., Neri, P., Koley, H., Batchu, R.B., Bertheau, R.C. Munshi, V., Prabhala, R., Fulciniti, M., Tai, Y.T., Treon, S.P., et al. (2006). Specific killing of multiple myeloma cells by (-)epigallocatechin-3-gallate extracted from green tea: biologic activity and therapeutic implications. Blood 108, 2804-2810.

Shamseddine, A.A., Airola, M.V., and Hannun, Y.A. (2015). Roles and regulation of neutral sphingomyelinase-2 in cellular and pathological processes. Adv. Biol. Regul. 57, 24-41.

Siow, D., and Wattenberg, B. (2011). The compartmentalization and translocation of the sphingosine kinases: mechanisms and functions in cell signaling and sphingolipid metabolism. Crit. Rev. Biochem. Mol. Biol. 46, 365-375.

Tafesse, F.G., Ternes, P., and Holthuis, J.C. (2006). The multigenic sphingomyelin synthase family. J. Biol. Chem. 281, 29421
29425

Tani, M., and Kuge, O. (2009). Sphingomyelin synthase 2 is palmitoylated at the $\mathrm{COOH}$-terminal tail, which is involved in its localization in plasma membranes. Biochem. Biophys. Res. Commun. 381, 328-332.

Taniguchi, M., and Okazaki, T. (2014). The role of sphingomyelin and sphingomyelin synthases in cell death, proliferation and migration-from cell and animal models to human disorders. Biochim. Biophys. Acta 1841, 692-703.

Taniguchi, M. Kitatani, K. Kondo, T. Hashimoto-Nishimura, M., Asano, S., Hayashi, A., Mitsutake, S., Igarashi, Y., Umehara, H. Takeya, H., et al. (2012). Regulation of autophagy and its associated cell death by "sphingolipid rheostat": reciprocal role of ceramide and sphingosine 1-phosphate in the mammalian target of rapamycin pathway. J. Biol. Chem. 287, 39898-39910

Taouji, S., Higa, A., Delom, F., Palcy, S., Mahon, F.X., Pasquet, J.M., Bosse, R., Segui, B., and Chevet, E. (2013). Phosphorylation of serine palmitoyltransferase long chain-1 (SPTLC1) on tyrosine 164 inhibits its activity and promotes cell survival. J. Biol. Chem. 288, 17190-17201.

Tettamanti, G., Bassi, R., Viani, P., and Riboni, L. (2003). Salvage pathways in glycosphingolipid metabolism. Biochimie 85, 423437.

Tomiuk, S., Hofmann, K., Nix, M., Zumbansen, M., and Stoffel, W. (1998). Cloned mammalian neutral sphingomyelinase: functions in sphingolipid signaling? Proc. Natl. Acad. Sci. USA 95, 36383643.

Truman, J.P., Garcia-Barros, M., Obeid, L.M., and Hannun, Y.A. (2014). Evolving concepts in cancer therapy through targeting sphingolipid metabolism. Biochim. Biophys. Acta 1841, 11741188 .

Tsukamoto, S., Hirotsu, K., Kumazoe, M., Goto, Y., Sugihara, K., Suda, T., Tsurudome, Y., Suzuki, T., Yamashita, S., Kim, Y., et al. (2012). Green tea polyphenol EGCG induces lipid-raft clustering and apoptotic cell death by activating protein kinase Cdelta and acid sphingomyelinase through a $67 \mathrm{kDa}$ laminin receptor in multiple myeloma cells. Biochem. J. 443, 525-534.

Turzanski, J., Grundy, M., Shang, S., Russell, N., and Pallis, M. (2005). P-glycoprotein is implicated in the inhibition of ceramideinduced apoptosis in TF-1 acute myeloid leukemia cells by modulation of the glucosylceramide synthase pathway. Exp. Hematol. 33, 62-72.

Vacaru, A.M., Tafesse, F.G., Ternes, P., Kondylis, V., Hermansson, M., Brouwers, J.F., Somerharju, P., Rabouille, C., and Holthuis, J.C. (2009). Sphingomyelin synthase-related protein SMSr controls ceramide homeostasis in the ER. J. Cell Biol. 185, 10131027.

Wallington-Beddoe, C.T., Hewson, J., Bradstock, K.F and Bendall, L.J. (2011). FTY720 produces caspase-independent cell death of acute lymphoblastic leukemia cells. Autophagy 7, 707-715.

Wallington-Beddoe, C.T., Don, A.S., Hewson, J., Qiao, Q., Papa R.A., Lock, R.B., Bradstock, K.F., and Bendall, L.J. (2012). Disparate in vivo efficacy of FTY720 in xenograft models of Philadelphia positive and negative B-lineage acute lymphoblastic leukemia. PLoS One 7, e36429.

Wallington-Beddoe, C.T., Powell, J.A., Tong, D., Pitson, S.M., Bradstock, K.F., and Bendall, L.J. (2014). Sphingosine kinase 2 promotes acute lymphoblastic leukemia by enhancing MYC expression. Cancer Res. 74, 2803-2815.

Wang, Q., Zou, J., Zhang, X., Mu, H., Yin, Y., and Xie, P. (2014). Glucosylceramide synthase promotes Bcl-2 expression via the ERK signaling pathway in the K562/A02 leukemia drug-resistant cell line. Int. J. Hematol. 100, 559-566.

Watanabe, M., Kitano, T., Kondo, T., Yabu, T., Taguchi, Y. Tashima, M., Umehara, H., Domae, N., Uchiyama, T., and Okazaki, T. (2004). Increase of nuclear ceramide through caspase3-dependent regulation of the "sphingomyelin cycle" in Fasinduced apoptosis. Cancer Res. 64, 1000-1007.

Watters, R.J., Fox, T.E., Tan, S.F., Shanmugavelandy, S., Choby, J.E., Broeg, K., Liao, J., Kester, M., Cabot, M.C., Loughran, T.P et al. (2013). Targeting glucosylceramide synthase synergizes with C6-ceramide nanoliposomes to induce apoptosis in natura killer cell leukemia. Leuk. Lymphoma 54, 1288-1296.

Wu, B.X., Rajagopalan, V., Roddy, P.L., Clarke, C.J., and Hannun, Y.A. (2010). Identification and characterization of murine mitochondria-associated neutral sphingomyelinase (MA-nSMase) the mammalian sphingomyelin phosphodiesterase 5. J. Biol. Chem. 285, 17993-18002.

Yamaji, T., and Hanada, K. (2014). Establishment of HeLa cell mutants deficient in sphingolipid-related genes using TALENs. PLoS One 9, e88124. 
Yamaji, T., and Hanada, K. (2015). Sphingolipid metabolism and interorganellar transport: localization of sphingolipid enzymes and lipid transfer proteins. Traffic 16, 101-122.

Yamaoka, S., Miyaji, M., Kitano, T., Umehara, H., and Okazaki, T. (2004). Expression cloning of a human CDNA restoring sphingomyelin synthesis and cell growth in sphingomyelin synthase-defective lymphoid cells. J. Biol. Chem. 279, 18688-18693.

Yildiz, Y., Matern, H., Thompson, B., Allegood, J.C., Warren, R.L., Ramirez, D.M., Hammer, R.E., Hamra, F.K., Matern, S., and Russell, D.W. (2006). Mutation of beta-glucosidase 2 causes glycolipid storage disease and impaired male fertility. J. Clin. Invest. 116, 2985-2994.

Yun, S.H., Park, E.S., Shin, S.W., Na, Y.W., Han, J.Y., Jeong, J.S. Shastina, V.V., Stonik, V.A., Park, J.I., and Kwak, J.Y. (2012). Stichoposide C induces apoptosis through the generation of ceramide in leukemia and colorectal cancer cells and shows in vivo antitumor activity. Clin. Cancer Res. 18, 5934-5948.

Zeidan, Y.H., Jenkins, R.W., and Hannun, Y.A. (2008). Remodeling of cellular cytoskeleton by the acid sphingomyelinase/ceramide pathway. J. Cell Biol. 181, 335-350.

Yun, S.H., Park, E.S., Shin, S.W., Na, Y.W., Han, J.Y., Jeong, J.S Shastina, V.V., Stonik, V.A., Park, J.I., and Kwak, J.Y. (2012) Stichoposide $\mathrm{C}$ induces apoptosis through the generation of ceramide in leukemia and colorectal cancer cells and shows in vivo antitumor activity. Clin. Cancer Res. 18, 5934-5948.

Zeidan, Y.H., Jenkins, R.W., and Hannun, Y.A. (2008). Remodeling of cellular cytoskeleton by the acid sphingomyelinase/ceramide pathway. J. Cell Biol. 181, 335-350.

Zembruski, N.C., Nguyen, C.D., Theile, D., Ali, R.M., Herzog, M., Hofhaus, G., Heintz, U., Burhenne, J., Haefeli, W.E., and Weiss, J. (2013). Liposomal sphingomyelin influences the cellular lipid profile of human lymphoblastic leukemia cells without effect on P-glycoprotein activity. Mol. Pharm. 10, 1020-1034.

Zhang, Y.Y., Xie, K.M., Yang, G.Q., Mu, H.J., Yin, Y., Zhang, B., and Xie, P. (2011). The effect of glucosylceramide synthase on $\mathrm{P}$-glycoprotein function in K562/AO2 leukemia drug-resistance cell line. Int. J. Hematol. 93, 361-367.

Zhang, P., Chen, Y., Cheng, Y., Hertervig, E., Ohlsson, L., Nilsson A., and Duan, R.D. (2014). Alkaline sphingomyelinase (NPP7) promotes cholesterol absorption by affecting sphingomyelin levels in the gut: A study with NPP7 knockout mice. Am. J. Physiol. Gastrointest Liver Physiol. 306, G903-908.

Zumbansen, M., and Stoffel, W. (2002). Neutral sphingomyelinase 1 deficiency in the mouse causes no lipid storage disease. Mol. Cell Biol. 22, 3633-3638. 